\title{
OSWALD MATHIAS UNGERS: \\ DIALECTICAL PRINCIPLES OF DESIGN
}

\author{
Sam Jacoby
}

Architectural Association School of Architecture, UK

This is an Accepted Manuscript by Taylor \& Francis for publication in The Journal of Architecture on 29.05.2018 


\begin{abstract}
An important contributor to the post-war debate on architecture's relationship to the city was the German architect Oswald Mathias Ungers (1926-2007). Starting in the early 1960s, he became increasingly interested in questions of typological organisation and morphological transformation, positing their relationship in dialectical principles. This paper traces some of the shifts in Ungers's understanding of architecture through a utilisation of typology as a design theme, the morphological transformation of architectural form, and the coincidence of opposites in urban building complexes by reviewing a selection of closely linked pieces of design research (lectures, writings, and large-scale housing projects) from the 1960 s to 80 s.
\end{abstract}

This paper examines how Ungers's interest in rational design as a problem of serial formal and social transformations led him to new understandings of architectural and urban design. The concepts of typology and morphology hereby played a central role in reclaiming architecture as a formal and intellectual, but also a social and imaginative project, through which the city could be reasoned, however, always through the problems arising from architectural form itself. 


\section{INTRODUCTION}

Oswald Mathias Ungers (1926-2007) was an influential post-war German architect and important voice in the growing European debate on architecture's relationship to the city in the $1960 \mathrm{~s}$ to $80 \mathrm{~s}$. His exchange with prominent figures such as the Smithson's, Also Rossi, and Colin Rowe influenced his early theories and design thinking that shared many of the concerns of Team Ten and Neorationalism. ' Ungers saw architecture as a synthesis of art and techné, as a tension between rationality and poetics, as well as between an elementary form and representational image, which were all persistent themes underlying the continuously changing paradigms of his architectural and urban design doctrine." Ungers's designs up to the 1980s express this preoccupation with dialectical complementarities, which is for example also evident in his studies of typology as morphology, the concept of the house-in-the-house, or his text 'Janus Face of Architecture'. Like many of his contemporaries, Ungers was both indebted to and critical of the Modern Movement in his search for an autonomous and rational language of architecture-seeking a disciplinary reasoning specific to architecture. In an attempt to explicate his approach to rational spatial design, he argued for the autonomy of architectural form based on a typological analysis that could uncover an elementary formal organisation of architecture and the city while responding to the realities of changing physical, sociocultural, and urban contexts.

While Ungers's work in the rich context of his institutional and personal relationships and collaborations, as well as biographical circumstances and political transformations in Germany and the USA has recently received much scholarly attention, most notably by Jasper Cepl in Oswald Mathias Ungers (2007) and André Bideau in Architektur und symbolisches Kapital (2011), this paper focusses on a discussion of the 'dialectical principles of design' that develop in his early designs, teaching, and writing. Their important overlaps and influences, especially in his design projects, have been little discussed in detail. Yet they are evidence of a sustained interest in a rational and methodical design approach and theory of composition linked to questions of typology and morphology. Especially Rossi's theory of typology in The Architecture of the City of 1966 as an irreducible 'apparatus' of architecture-which he associated with historical continuity and a reworking of already existing urban forms-can be recognised in Ungers's work that provides, however, a more concrete process of design. Ungers to some extent synthesised in his early oeuvre Rossi's understanding of typology as the formal analysis of the historical city and Carlo Aymonino's use of building typology and urban morphology as a method to analyse the functional elements of the city. ${ }^{\text {iii }}$ It is through the problem of typology and the possible morphological transformations it contains that Ungers develops an urban design strategy that is to both recognise the elementary forms of architecture and the necessary differentiated repetition and qualitative change of these architectural forms in urban situations.

A concern with a theoretical basis of design, but also Ungers's central concept of the 'housecity' as a conflation of architectural and urban scales, was first evident in the design for his own house in Cologne's Belvederestrasse (1959). ${ }^{\text {iv }}$ Ungers clarified the theoretical questions arising from practice itself subsequently in a series of typological and morphological studies in the 1960s, first explicitly in his candidate lecture for a professorial chair at the Technische Universität Berlin (TU Berlin) on $11^{\text {th }}$ February 1963, which marked his 'theoretical' building period lasting until the 1980s. In the candidate lecture, Ungers contended that the problem of architectural design derives from a fundamental principle of architectonic formation: the deduction of elementary form from architectural structure. ${ }^{\text {vi }}$ Discussing the formal principles of design, he claimed: 'Not the artistic moment is denoted by the term, but the objective 
structural that becomes clearly expressed as a principle in a building. In other words, the design elements, which the architect utilises to express and make visible his ideas. ${ }^{\text {'vi }}$ To explain this claim, he distinguished between the formation of spaces and figures that delimitate space, with the igloo being an example of an enclosed space, while the stone circle in Stonehenge in England exemplifies an open and in-between space defined by delimiting figures. This essentially understands architecture as a compositional problem of how to organise space-defining elements to enclose an interior, and defines it in specific disciplinary-or one can claim autonomous-terms. viii To illustrate a close connection between structural principle, design, and composition, Ungers showed an especially made 'tool kit'. Consisting of 1 cube, 6 surfaces, and 12 rods, the parts of the tool kit could be combined in different ways to form a cubic space, thereby demonstrating the three elementary structural principles of architectonic space: volume, surface and line. By then combining these formative elements, a progressively hybrid composition is possible in which qualitative tensions between inside and outside, positive and negative, and enclosed and delimited spaces emerge, until eventually resulting in a decomposition of individual elements in favour of a unified and three-dimensional spatial complex. This decomposing of tectonic elements into opposite yet complementary spatial qualities epitomised to Ungers a dialectical principle of design.

Ungers's understanding of architectural design as productively exploring a constant slippage between figure and space at different scales owes to Herman Sörgel's concept of architecture as Janus-faced, as discussed in Architektur-Ästhetik (Architectural Aesthetic, 1918). Ungers wrote in 1986 that Sörgel's claim that architecture is 'the formation of our entire spatial environment; from the vastness of space in nature right down to the smallest spatial unit of furniture', discloses the 'dialectic between man and the environment, and the creative dialogue between architecture and its environment'. ${ }^{\text {ix }}$ This notion of complementary architectonic space as ambivalent and simultaneously creating an architectural interior and urban exterior through an enclosing element such as a wall, was before Sörgel conceptualised by Gottfried Semper. To Semper, the 'four elements of architecture' (hearth, roof, enclosure, and mound) are the tectonic elements through which social relationships become spatially and materially manifest at both the interior scale of the house and the exterior scale of the city. ${ }^{x}$ While the socio-cultural context conditions the transformations of Semper's four elements, it is principally through the motive of dressing-the question of the envelope and its definition of an interior and exterior-that the material transformations (Stoffwechsel) preceding new spatial formations and conceptions are legible. Thus, when Ungers agrees with Sörgel that column, wall, and building define both an inside and outside space, he can be said to agree with Semper's double meaning of the dressed wall. ${ }^{\mathrm{i}}$

\section{TYPOLOGY AS THEME}

The definition of spatial design in Ungers's candidate lecture invokes what could be termed a 'typological diagram', meaning a diagrammatic condition in which conceptual and actual, specific problems of design coexist. Simultaneously dealing with a generative set of design problems and the possible formal expression of the generic in specific form, the typological diagram hereby sets limits to potential descriptions, analyses, and formal projections by introducing disciplinary terms, such as structural and organisational conventions or requirements. In Ungers's early work, these limits are in particular defined as a typological theme. 
Successful in his bid for the chair of Design and Building Theory at the TU Berlin, Ungers developed his ideas on architectural composition into principles for a typologicaldiagrammatic description and analysis in a series of lectures on museums, known as the Berlin Lectures 1964-65. By discussing the formal development of the museum genre, the lectures sought a new classification according to formal aesthetic criteria rather than functional aspects or historical chronology. Although the comparative study took into account the effects of lighting, curation, and stylistic elements of composition, the principal aim was to formulate a universal architectural system of classification that could be applied to all formal building typologies. It established a comprehensive classification of museum buildings according to part-to-part and part-to-whole relationships and was influenced by Friedrich Ostendorf's Sechs Bücher vom Bauen (Six Books on Building, 1913-23) as well as Eugen Ehmann's Der moderne Baustil: Ein Beitrag zur Klarstellung des Wesens der neuen Architekturen im Anfang des 20. Jahrhunderts in Deutschland (The Modern Building Style: A Contribution to Clarifying the Nature of New Architectures in the Early 20th Century in Germany, 1919). ${ }^{\text {xii }}$ Especially Ostendorf proposed an artistic theory of the architectonic work as a spatial imagination that responds to specific external contexts and internal functional requirements of a building. He classified buildings according to one or multiple room typologies and the relationship of their formal appearance to the creation of exterior and interior spaces. Ungers employed a similar classification by grouping the museum genre into three typologies: one-room buildings, multi-room buildings, and building complexes.

Ungers, however, expanded and systematised his classificatory scheme. First, by distinguishing between 'one-room, un-oriented buildings' with a self-contained form based on a square, rectangular or circular plan. He subsequently studied 'one-room buildings with a defined surrounding-space (Umraum)', which are regular buildings defined by delimiting perimeter elements, or irregular buildings with an axial extension to a defined exterior space. While these buildings are generally self-contained, their main spaces are demarcated by delimiting figures. Next, Ungers discussed 'multi-room buildings with equal disposition', buildings with comparable yet (stylistically) differentiated spatial units disposed within a coordinating matrix organised by an enfilade, corridor access or other connecting circulation elements. At times, these buildings form an inner courtyard, an exterior but enclosed central space that is integrated with the interior. Circulation and access also determined the following category of 'multi-room buildings with a clear configuration', in which spatial units are ordered by a connecting element (aisle, gallery, corridor, arcade, pergola, alley, street, boulevard, avenue or square) that either form a circulatory link with multiple directions, a single sinuous link between two points, a linear connection, or a connecting spiral. Through the combination of connecting circulation typologies, a multitude of enclosed and delimited spaces can be described. Finally, Ungers analysed 'building complexes with a simple composition of building elements', which are centred and have multiple building directions (ranging from linear to a cruciform configuration and from a cruciform to a free-form arrangement around an open centre), and 'building complexes with a compound composition of building elements', which are centre-less and un-oriented clusters of buildings with an accumulative or combinatory arrangement without an apparent ordering principle besides functional or compositional criteria.

Having developed a new classification of museums, Ungers concludes the Berlin Lectures by discussing Fritz Wolf's first design for the Pergamonmuseum (completed in 1899) to argue for the dialectical principle as an important basis for his taxonomy by stating: 'The concept of the Pergamonmuseum was a house in the house, that in enclosing enclosed, within the precious the even more precious, within the visible the invisible. A metaphor thus 
for all that unfolds. ${ }^{\text {xii }}$ As the lectures convey, he is not merely interested in the museum as a genre, a group of buildings defined by function, but in how to establish a universal building classification that transcends functions and uses the formal disposition of building elements to define the interior and exterior relationships of spatial complexes. The theme of the house-in-the-house also conveys an idea of morphological transformation, as the interrelation between architecture and city suggests a morphological scalability of typologies. Ungers's idea of morphological transformation, despite appropriating a universal classification of form, however conceptually opposes standardisation. ${ }^{\text {xiv }}$ To Ungers, the superimposition, extension, and contradiction inherent to the concept of the house-in-thehouse results in a continuous historical process, but also a deliberate rupture of continuity to force change. Thus, either time or design-or both—challenge the separation of inside and outside, the opposition of enclosed and enclosing, and the contradiction of figure and space: the formative and complementary elements of architectonic space.

This interest in a typological limit as a design problem was also evident in a series of six weekly design exercises (Wochenaufgaben) Ungers gave to his students. Concurrent with the lectures in 1964-65, he asked students to respond to a fixed programme for a residential family house, but gave each week different formal, functional, thematic, material, site specific, and structural design constraints that had to be resolved in a design proposal. $\mathrm{He}$ termed each design constraint a 'theme', declaring that '[t]he series can be continued: always the same spatial programme, a residential building-it could also be a school, a kindergarten or any other typical assignment-and different specific constraints. The purpose of the task was to develop and get to know technical design constraints. ${ }^{x v}$ Expanding on the notion of the theme, Ungers in his book Architecture as Theme of 1982 expounded that a building without a theme is devoid of ideas and humanism, is condemned to satisfying need alone, as only the theme that emerges from within architecture itself provides a building with content. ${ }^{\text {xvi }}$ Ungers argued that the theme as a higher ordering principle of architecture requires an abstraction of immutable and fundamental spatial concepts specific to the architectural discipline, and that the 'focus of the New Abstraction is architecture as idea, as concepts, as themes. It is concerned with the autonomy of the architectural language'. xvii

Ungers developed a diagrammatic thinking and typological themes also in his own design work, as can be seen in one of his early large-scale housing project, the proposal for Neue Stadt Köln-Chorweiler (1961-65). The competition asked for new housing typologies for family homes and rental flats while providing schedules for flat sizes and inhabitable rooms. Responding to the masterplan drawn up by the local authority-which in Ungers's opinion lacked formal and spatial coherence-he proposed a typological solution that could be implemented at different scales (Figs. 1 and 2). In fact, the proposal returned to the compositional problem of delimiting, positive figures and their relationship to a central, negative space created in-between (Figs. 3-5). Each functional unit (1), such as bedroom or service and utility room (kitchen, bathrooms and storage areas) derives not from a subdivision of the plan, but is placed as a freestanding volume. By enclosing the gaps between these volumes with glass walls, two negative spaces are created: an interior living room (2) and exterior urban squares (Fig. 6). 


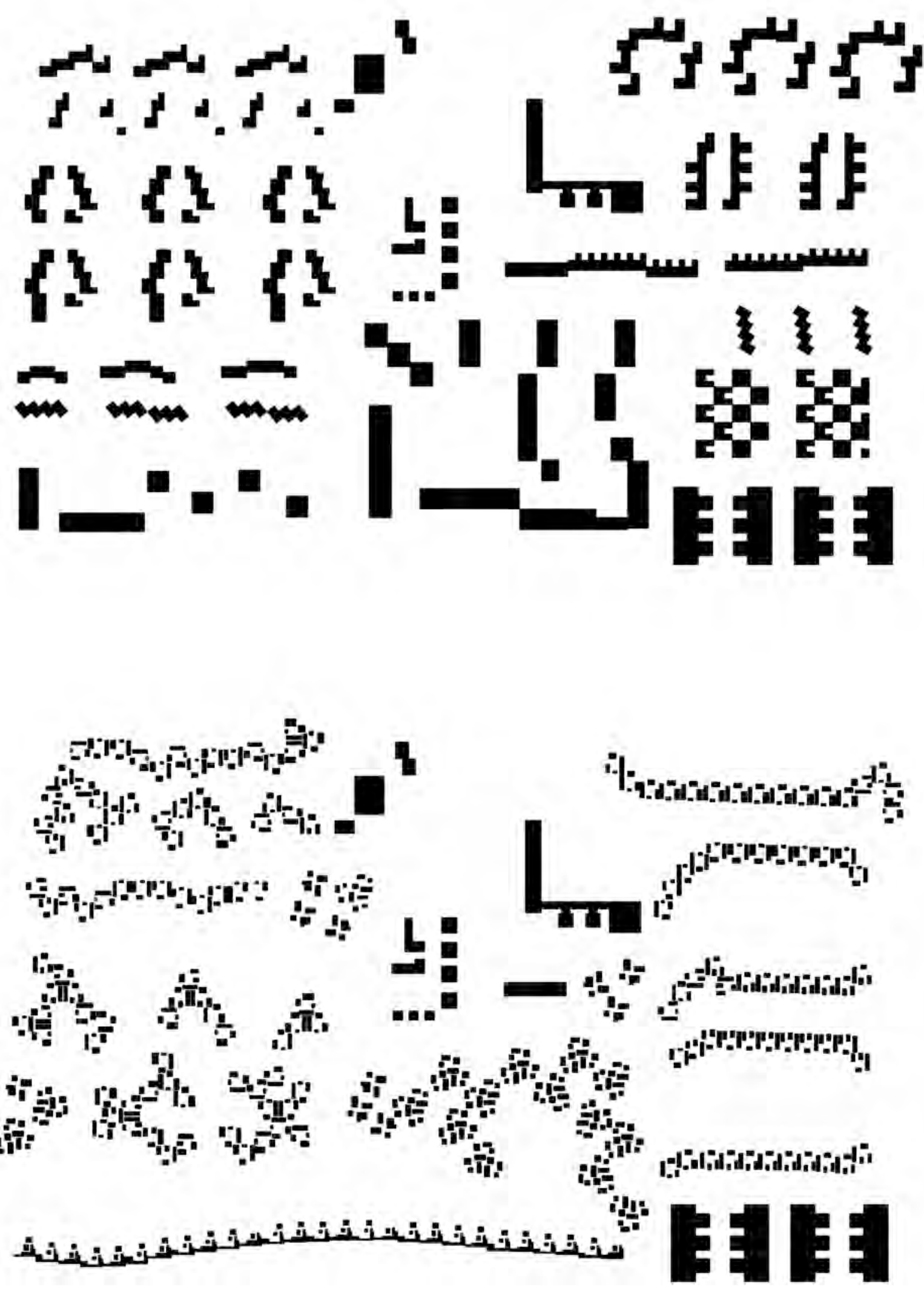

Figure 1

Figure-ground comparison of the masterplan by the city of Cologne from 1961 (top) and the competition entry for Neue Stadt Köln by O. M. Ungers (1962). Klaus Platzgummer, Tianyi Shu and Benedict Wahlbrink (Architectural Association School of Architecture, 2014). 


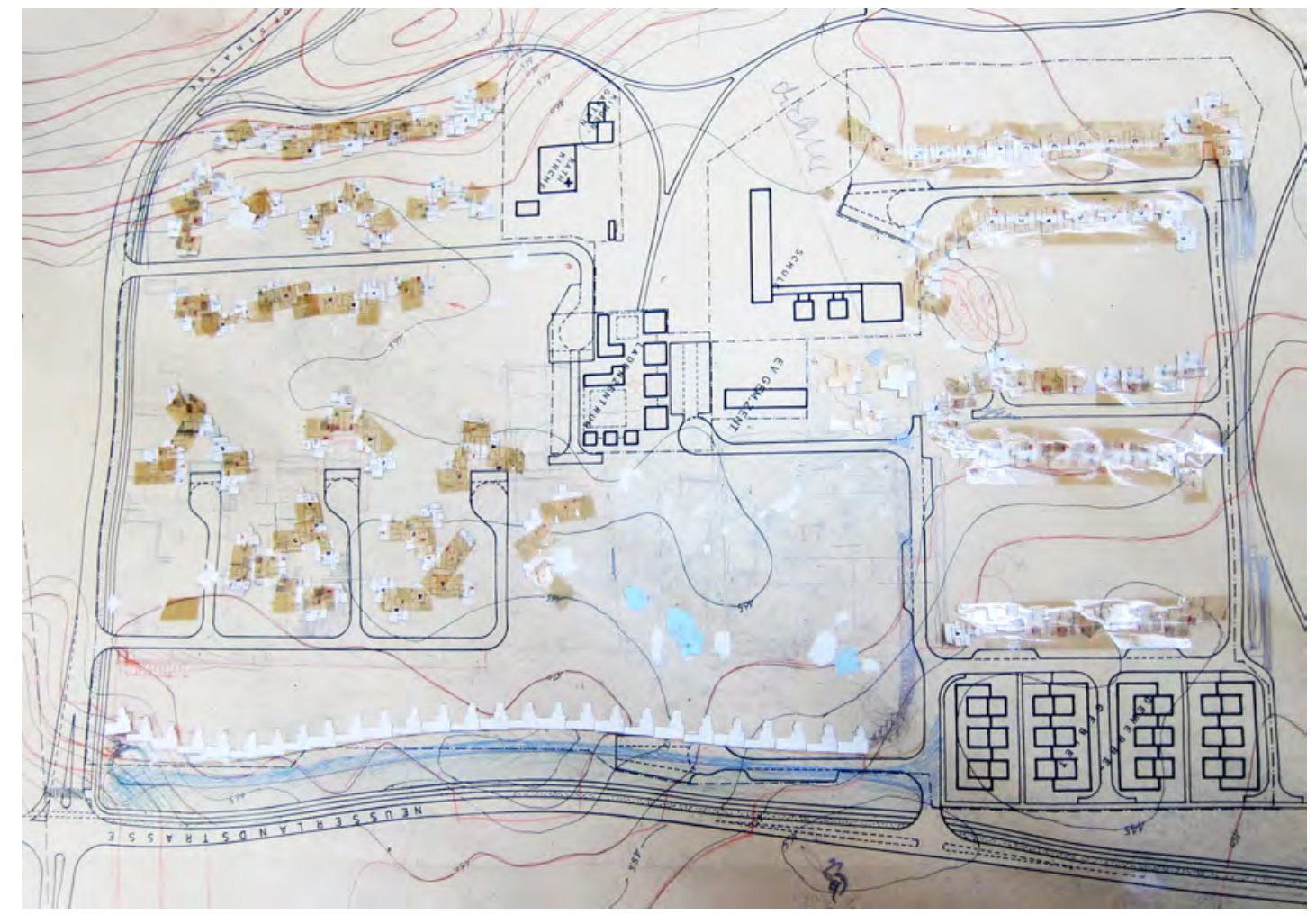

Figure 2

Layout study of masterplan (paper cut-outs of building clusters taped to site plan). O. M. Ungers, competition for Neue Stadt Köln (1962). Courtesy of the Ungers Archiv für Architekturwissenschaft.

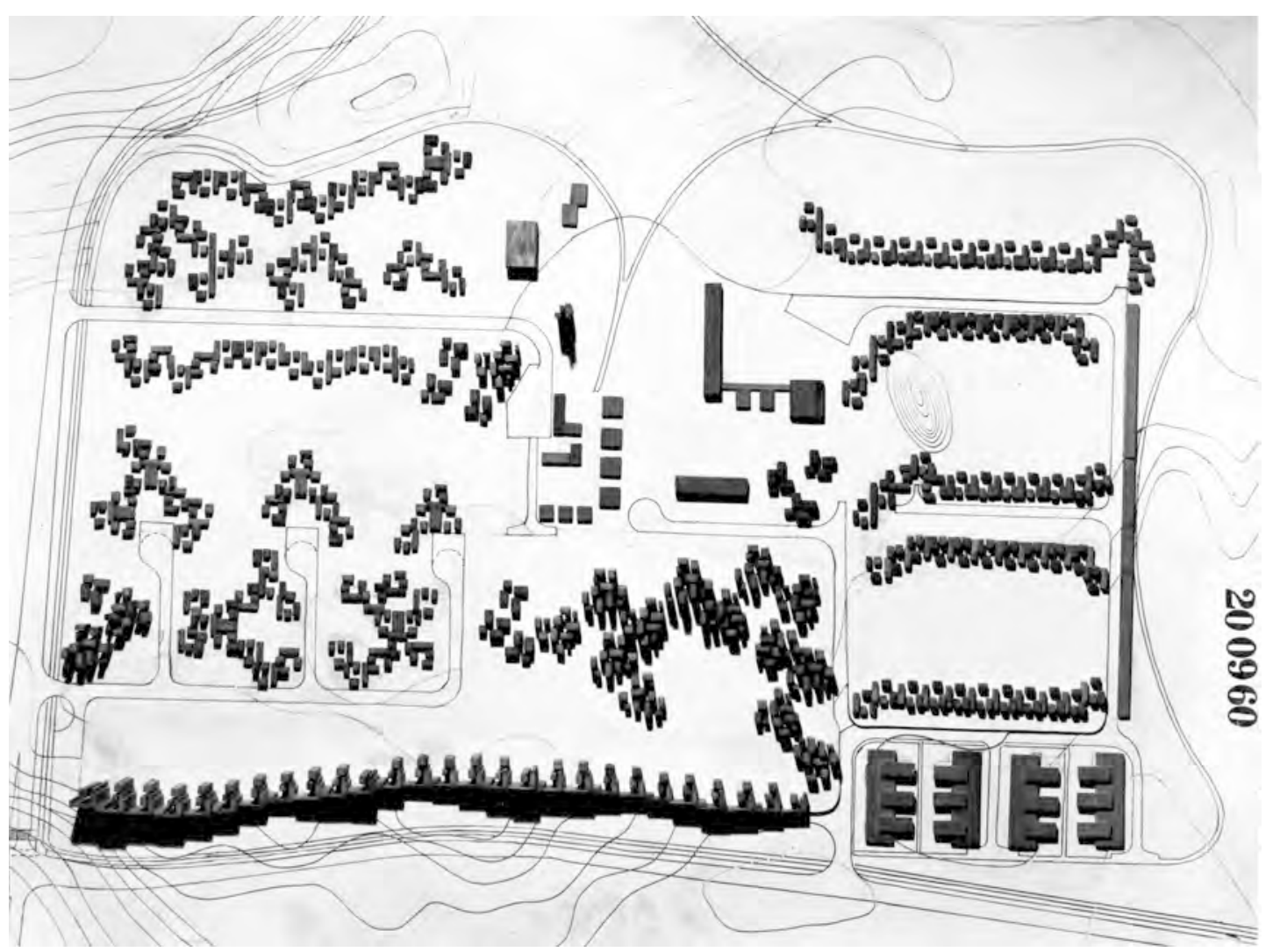

Figure 3

Top view of the masterplan model. O. M. Ungers, competition entry for Neue Stadt Köln-Chorweiler (1962). Courtesy of the Ungers Archiv für Architekturwissenschaft. 


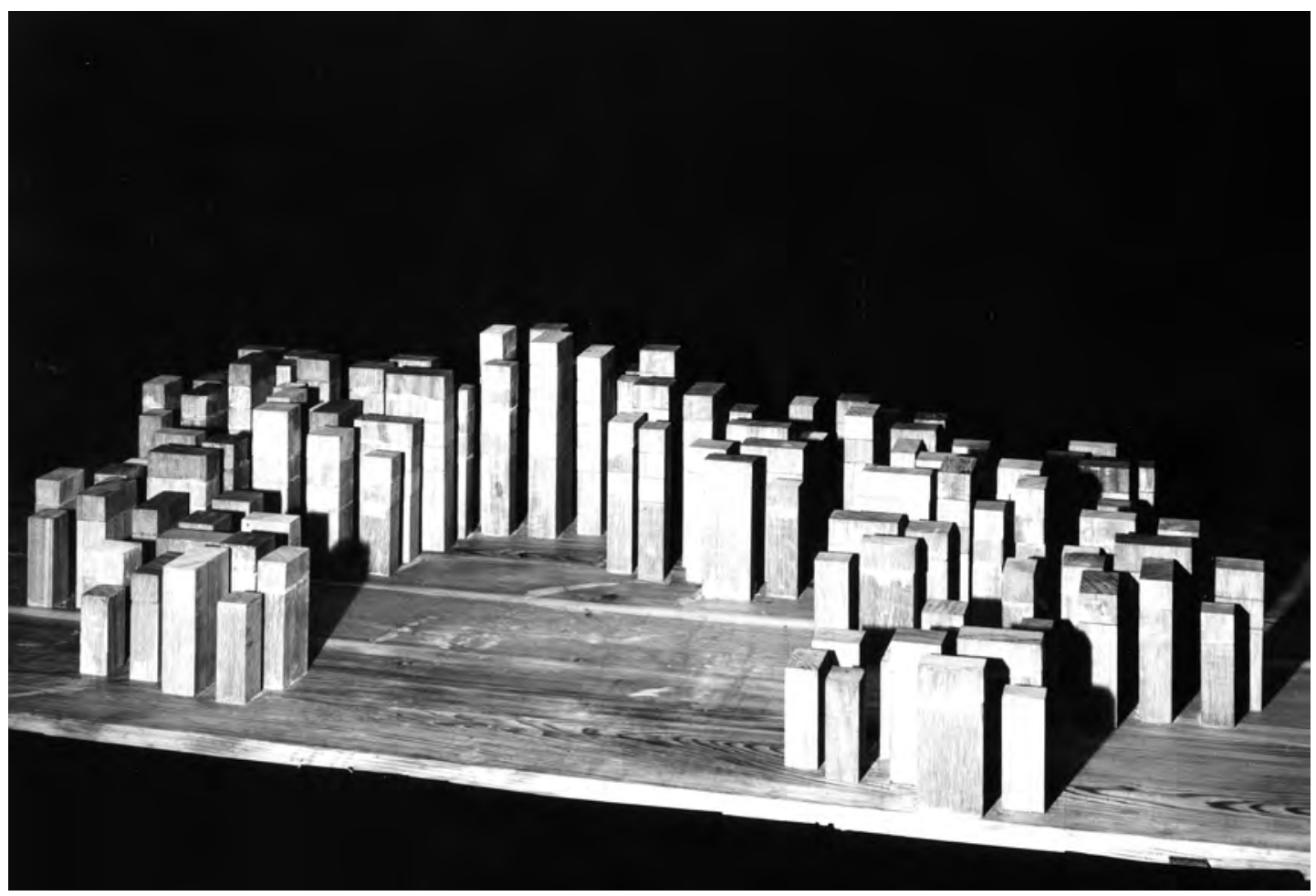

Figure 4

Model of the 'positive' spaces of housing typology with flats. O. M. Ungers, competition entry for Neue Stadt KölnChorweiler (1962). Courtesy of the Ungers Archiv für Architekturwissenschaft.

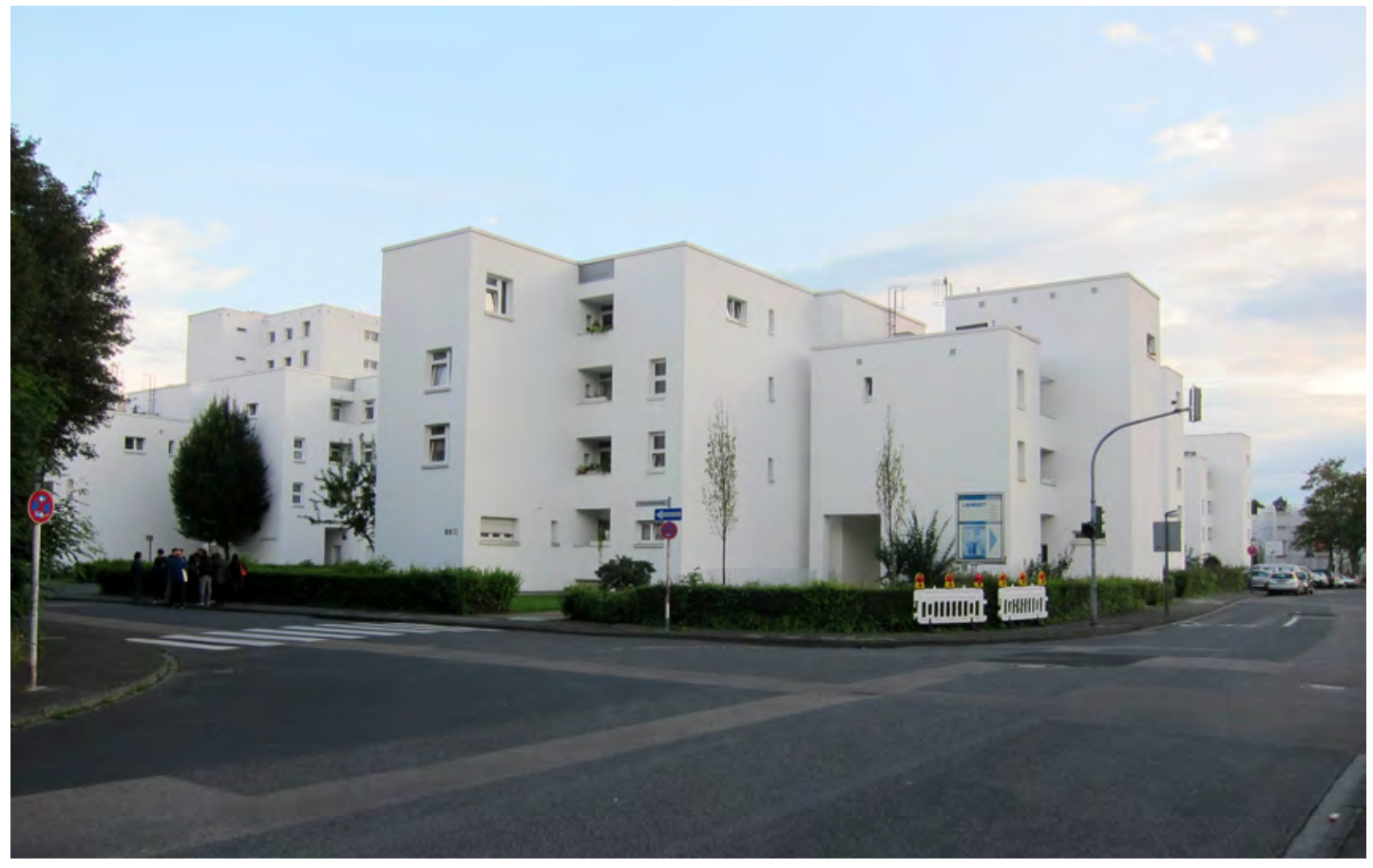

Figure 5

Photograph of Neue Stadt Köln as realised. Klaus Platzgummer, Tianyi Shu and Benedict Wahlbrink (Architectural Association School of Architecture, 2014). 

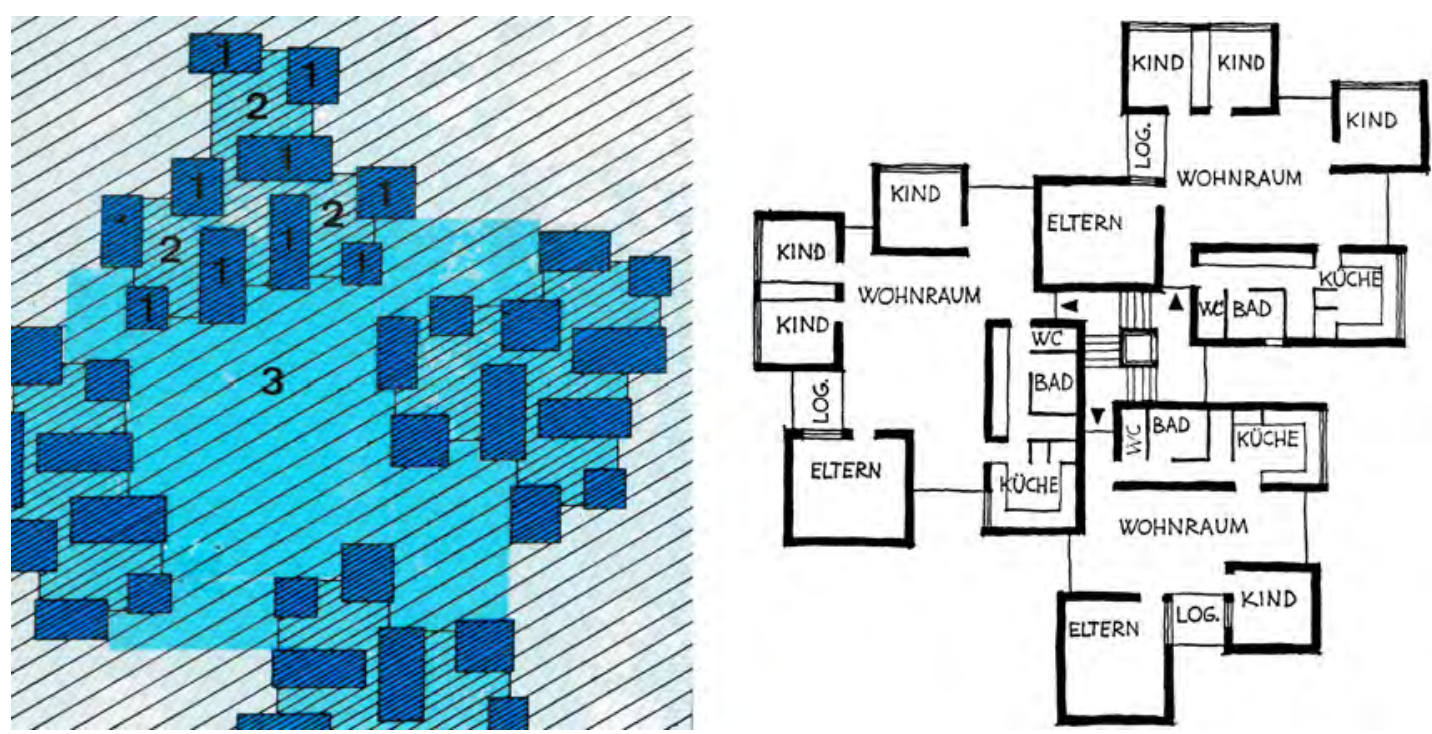

Figure 6

Typical organisational diagram of building cluster and sketch layout of a building unit. $\mathrm{O}$. M. Ungers, competition entry for Neue Stadt Köln-Chorweiler (1962). Left: 1. room, 2. living room, 3. urban square. Courtesy of the Ungers Archiv für Architekturwissenschaft.

Ungers referred to his functional units in the Neue Stadt Köln as Schlafhäuser (houses for sleeping) and Wirschaftshäuser (houses for services), indicating a correspondence between the function and scale of architectural and urban elements. ${ }^{\text {xviii }}$ Invoking Leon Battista Alberti's concept of compartition, he described the city as a morphological complex deriving from a transformation of elementary architectural typologies. Explaining compartition as a morphological complementarity of parts, Alberti wrote: 'If', as the philosopher maintains, 'the city is like some large house, and the house is in turn like some small city, cannot the various parts of the house-atria, xysti, dining rooms, porticoes, and so on-be considered miniature buildings? ${ }^{\text {xix }}$ In the design for Neue Stadt Köln, this differentiated spatial meaning is related to various ideas of communality. At the level of the flat, it exacerbates the difference between private and shared spaces, as each room (house) is physically separated, with the living room placed in such a way that social interactions between members of the household (neighbourhood) are increased, thereby functioning, to Ungers, like an 'urban square'. A comparable relationship between architectural form and social interaction occurs within the housing block, made up of clusters of three flats each and distributed around a central access core, as well as the next larger scale between the housing blocks, when a number of exterior 'urban' squares are formed. Thus, a formal architectural solution produces different spatial and social qualities at different scales (Fig. 7). What this design approach also makes evident is that a typological idea becomes especially effective and legible as an urban strategy, as this demands from it the creation of multiple qualities, which reveal typology rather as a transformative than static problem. Likewise, while Alberti's analogy predominantly refers to formal part-to-part relations, Ungers's house-in-the-house analogy is enriched by a social and urban ambition which, however, in later projects such as the German Architecture Museum in Frankfurt (1984) seem to be abandoned for a return to a purely formal agenda. 


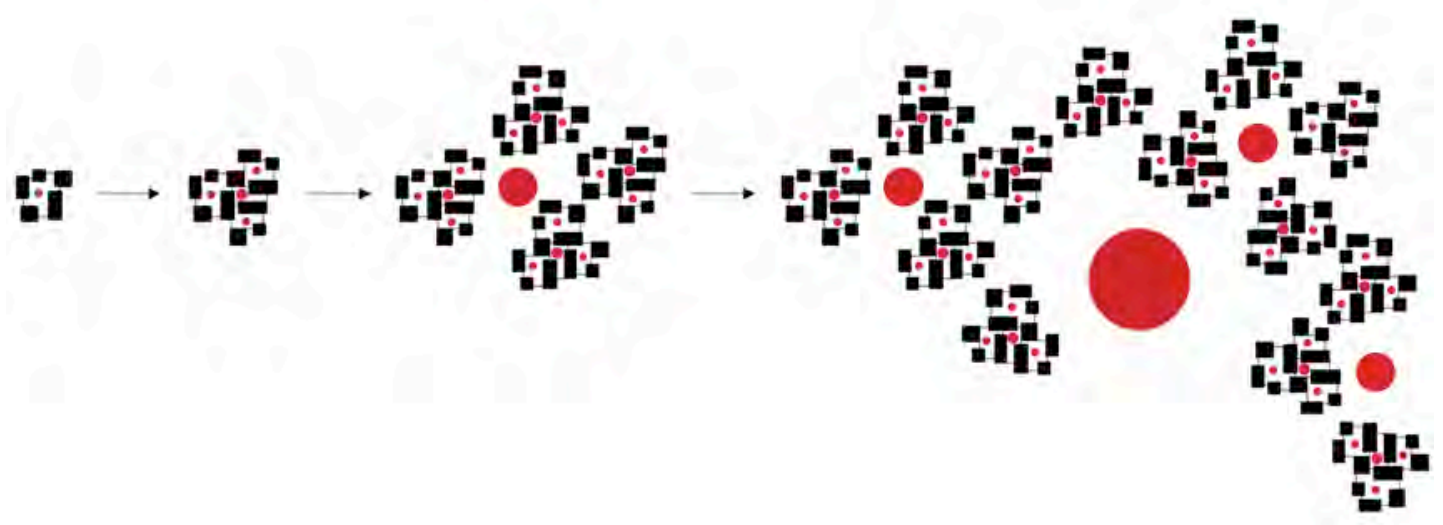

Figure 7

Diagram of negative and positive (public) spaces (indicated in red) and their incremental order in the proposal for Neue Stadt Köln-Chorweiler by O. M. Ungers. Klaus Platzgummer, Tianyi Shu and Benedict Wahlbrink (Architectural Association School of Architecture, 2014).

The competition scheme for Neue Stadt Köln was greatly revised in 1963 for realisation on just one of the plots in the masterplan. Although the design brief also changed from large family dwellings to flats for couples or families with a single child, the idea of positive and negative spaces was maintained, with Ungers rationalising the floorplan through a crossshaped layout (Fig. 8). For the housing project Märkisches Viertel in Berlin (1962-67), which was designed in parallel to, and completed shortly after, the Neue Stadt Köln, Ungers would develop a variation of these flat and housing plans (Fig. 9).
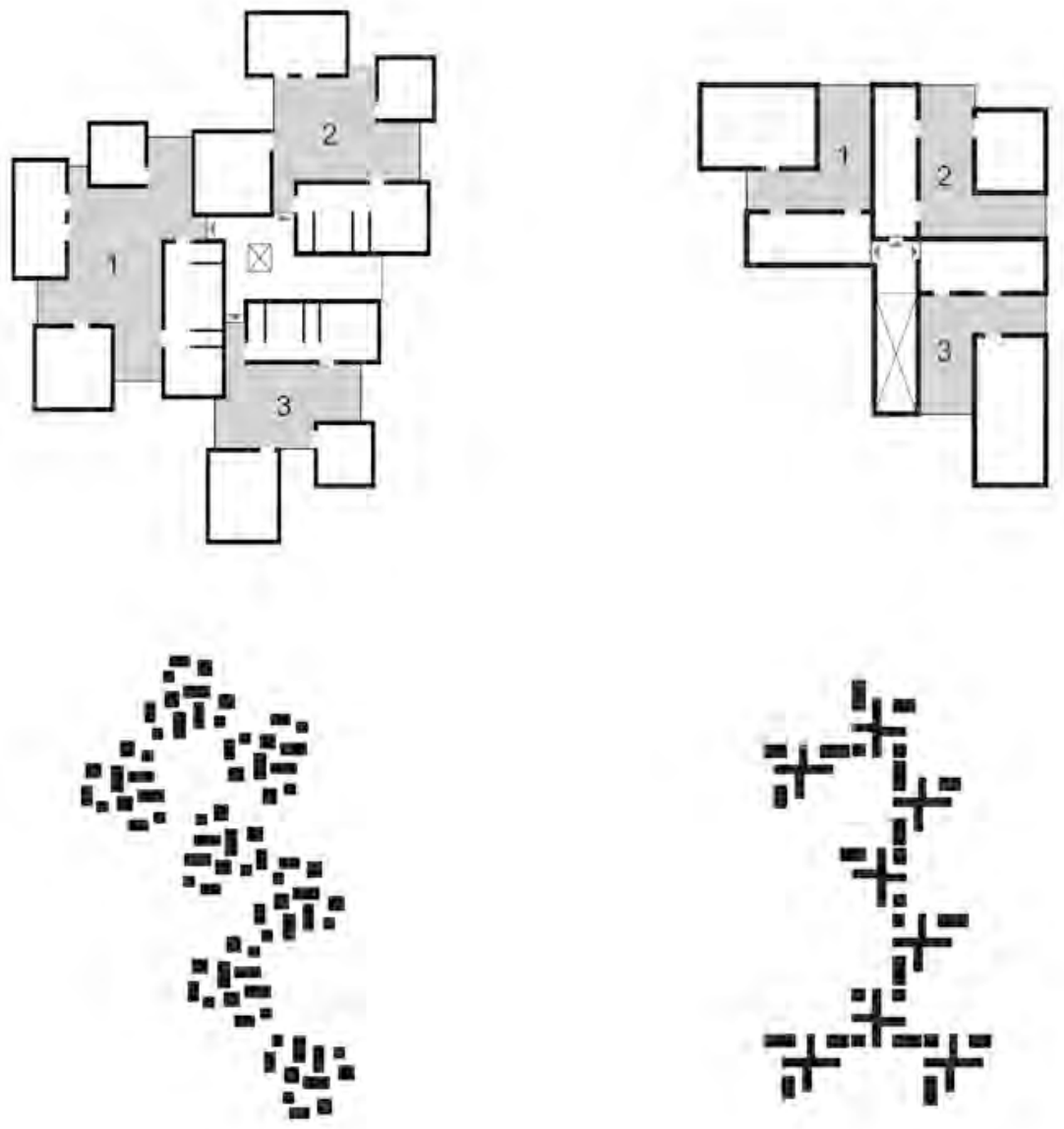

Figure 8

Comparison of competition design (left) and built cluster of three flats (right) in Plot 1 of Neue Stadt KölnChorweiler by O. M. Ungers. Klaus Platzgummer, Tianyi Shu and Benedict Wahlbrink (Architectural Association School of Architecture, 2014). 


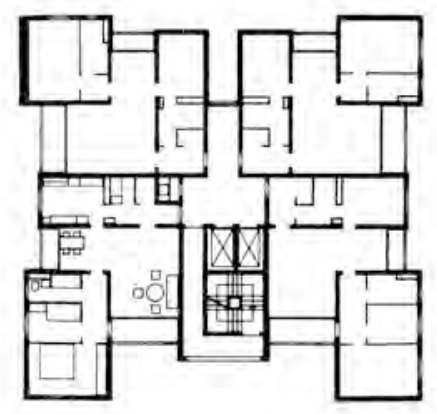

Figure 9

Typical floorplan of housing unit in Märkisches Viertel, Berlin. O. M. Ungers (1962-67). Courtesy of the Ungers Archiv für Architekturwissenschaft.

\section{MORPHOLOGICAL TRANSFORMATION}

The different flat typologies found in the various proposals for Neue Stadt Köln and Märkisches Viertel also reappeared in preliminary design studies for student housing at the University of Technology, Twente, the Netherlands, from early 1964-the same year Ungers gave his Berlin Lectures. He later described this competition entry as his 'very personal manifesto of a morphological architecture', ${ }^{x x}$ and claimed that the first design studies were inspired by Jean-Nicolas-Louis Durand to develop an 'encyclopaedia of forms' and spatial morphologies by applying incremental modifications such as 'rupture, folding, repetition, superimposition, subdivision, permutation, doubling, reflection, arrangement in series, etc'xi to the basic geometries of circle, square, and triangle (Fig. 10). While these explanations might have been a post-rationalisation not uncommon for Ungers, his early interest in Durand is supported by the inclusion of Antonio Hernandez's paper 'Jean-Nicolas-Louis Durand und die Anfänge einer funktionalistischen Architekturtheorie' ('JNL Durand and the Beginning of a Functionalist Architectural Theory') in a symposium on architectural theory at the TU Berlin organised by him in 1967. xxii The resultant matrices for the three basic building arrangements according to the geometric typologies of square, circle, and triangle (applied as 90 -degree angle, semi-circular, and variable angle) showed a range of possible formal transformations (Fig. 11).

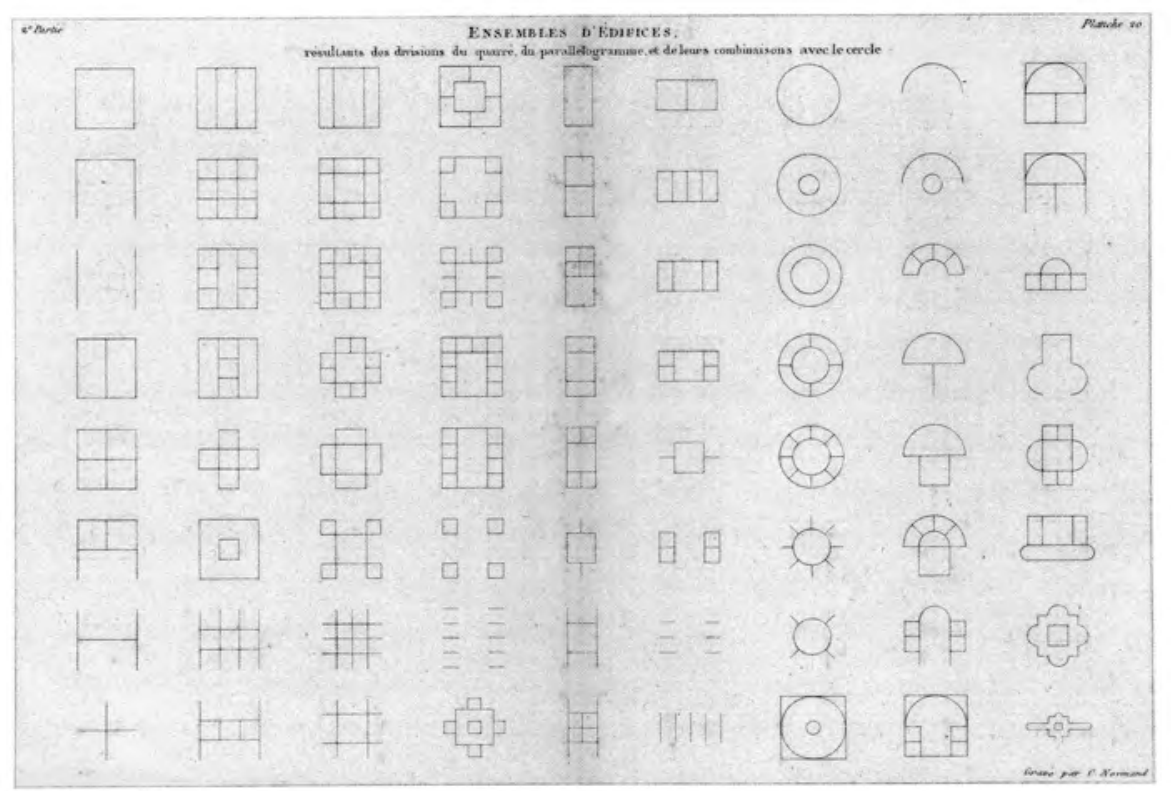




\section{Figure 10}

'Plate 20, Ensemble d'édifices, résultants de divisions du carré, du parallélogramme et de leurs combinaisons avec le cercle' [Building Ensembles, Resulting from the Divisions of the Square, the Parallelogram and Their Combinations with the Circle], in Jean-Nicolas-Louis Durand, Précis des leçons d'architecture données à l'École Royale Polytechnique, vol 1 (Paris: the author, 1802).
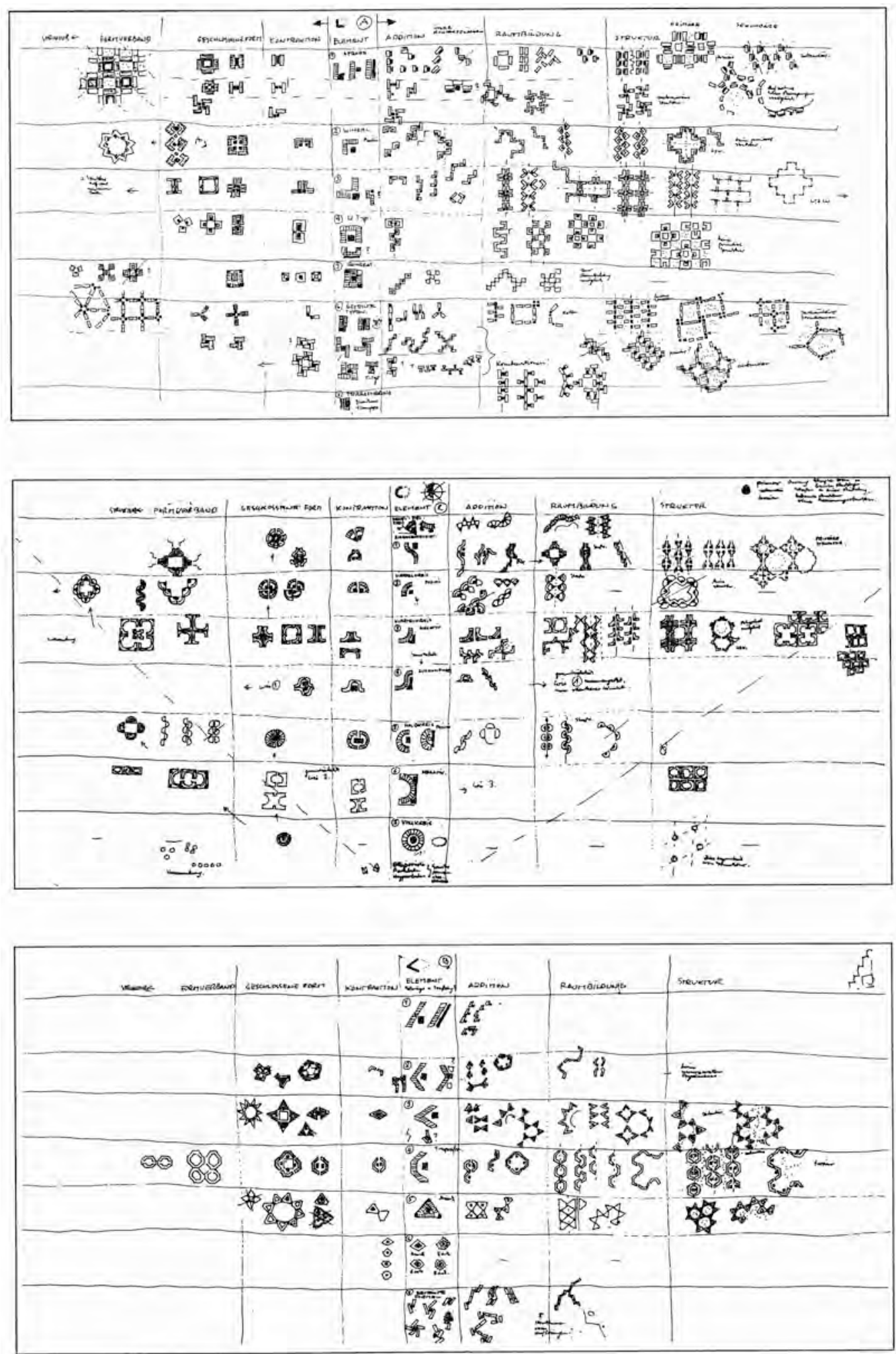

Figure 11

Study of morphological transformation of rectangular, circular and triangular formal building elements. $\mathrm{O}$. M. Ungers, student housing competition for TH Twente, Enschede, the Netherlands (1963-64). Courtesy of the Ungers Archiv für Architekturwissenschaft 
Yet, what were considered meaningful instances in these matrices? The conceptual design sketches and notes, most likely by Jonas Geist, provide a partial answer to the question (Fig. 12). ${ }^{x x i i}$ The stated aim of the project was to study the extremes of student housing: from one house for one student, to student hotels and communal housing. Thus, as the notes confirm, it was about the 'possibility of choice, however, not within a heterogeneous structure (Gebilde), but within a single housing-form (Wohn-Leib). The housing complex has to support the form and not the group.' In other words, the aim was not simply the assembly of buildings and their cellular parts, but the creation of a larger coherent form: a building complex (Fig. 13). The notes also explain how a basic element of student housing consisting of 15 cells and communal spaces can be developed in relationship to three circular, rectangular, and triangular geometric typologies. These typologies can be combined in order to form a spatial and structural complex (Fig. 14). The notes even provide parameters for the 'declension' of individual elements, which are basic formal transformations (e.g. addition, offset, shift, juxtaposition, compression, etc.), as well as for the classification of structural complexes, which define morphological ranges of spatial organisation (e.g. from solid volume to dissolved mass, from road to square, etc.). Applying these parameters to the student housing elements, a variety of possible layouts with individual and collective housing units are created (Fig. 15). The matrices then are essentially combinations of classificatory parameters and transformations of elements according to the basic options of distributing the elements in a linear, angular, or square order (Fig. 11). It is another attempt to understand how typology relates to morphology, how a part-to-part relationship transforms and works across different scales. The concept sketches start with a typological problem-not a functional problem-and try to work out how formal and social diagrams relate, in this specific case, how student housing can reflect on a variety of private and communal housing demands by different parts of the same constituency, and the architectural and urban forms this creates.

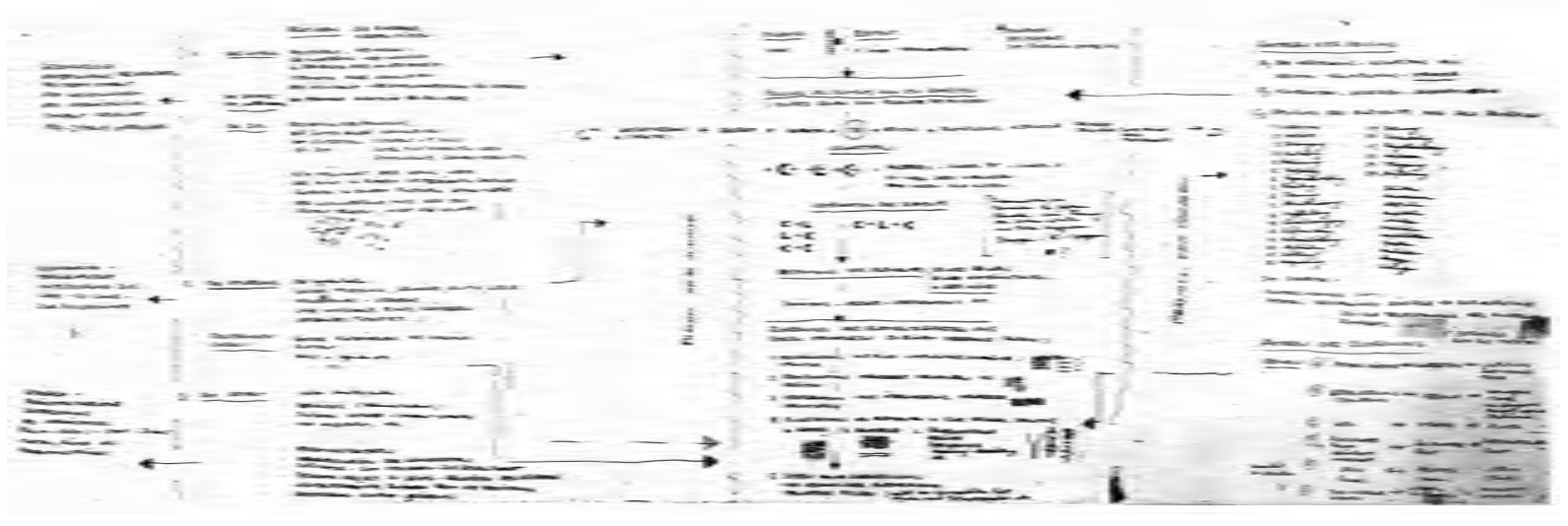

Figure 12

Concept sketches and notes. O. M. Ungers, student housing competition for TH Twente, Enschede, the Netherlands (ca 1963). Courtesy of the Ungers Archiv für Architekturwissenschaft 


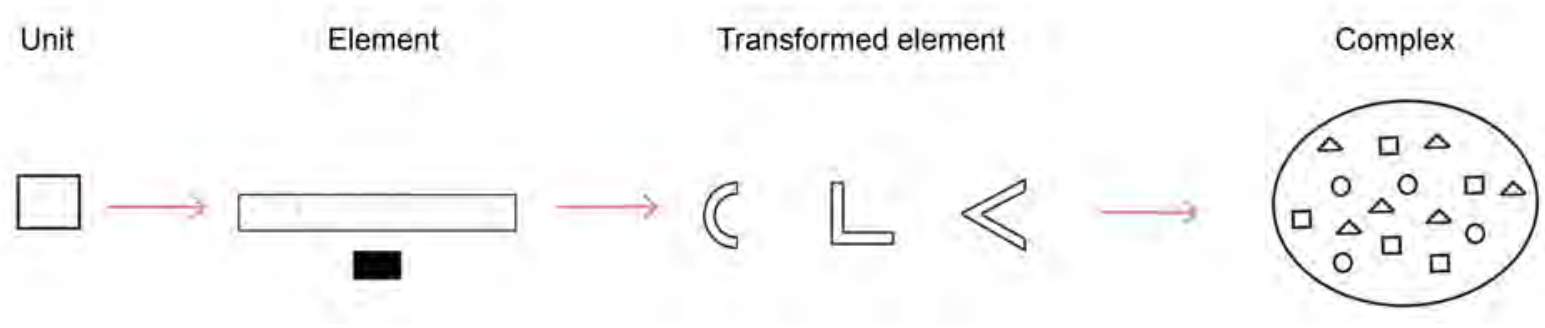

Figure 13

From unit to element and its transformation into a complex. Yana Petrova and Felix Zohlen (Architectural Association School of Architecture, 2014).

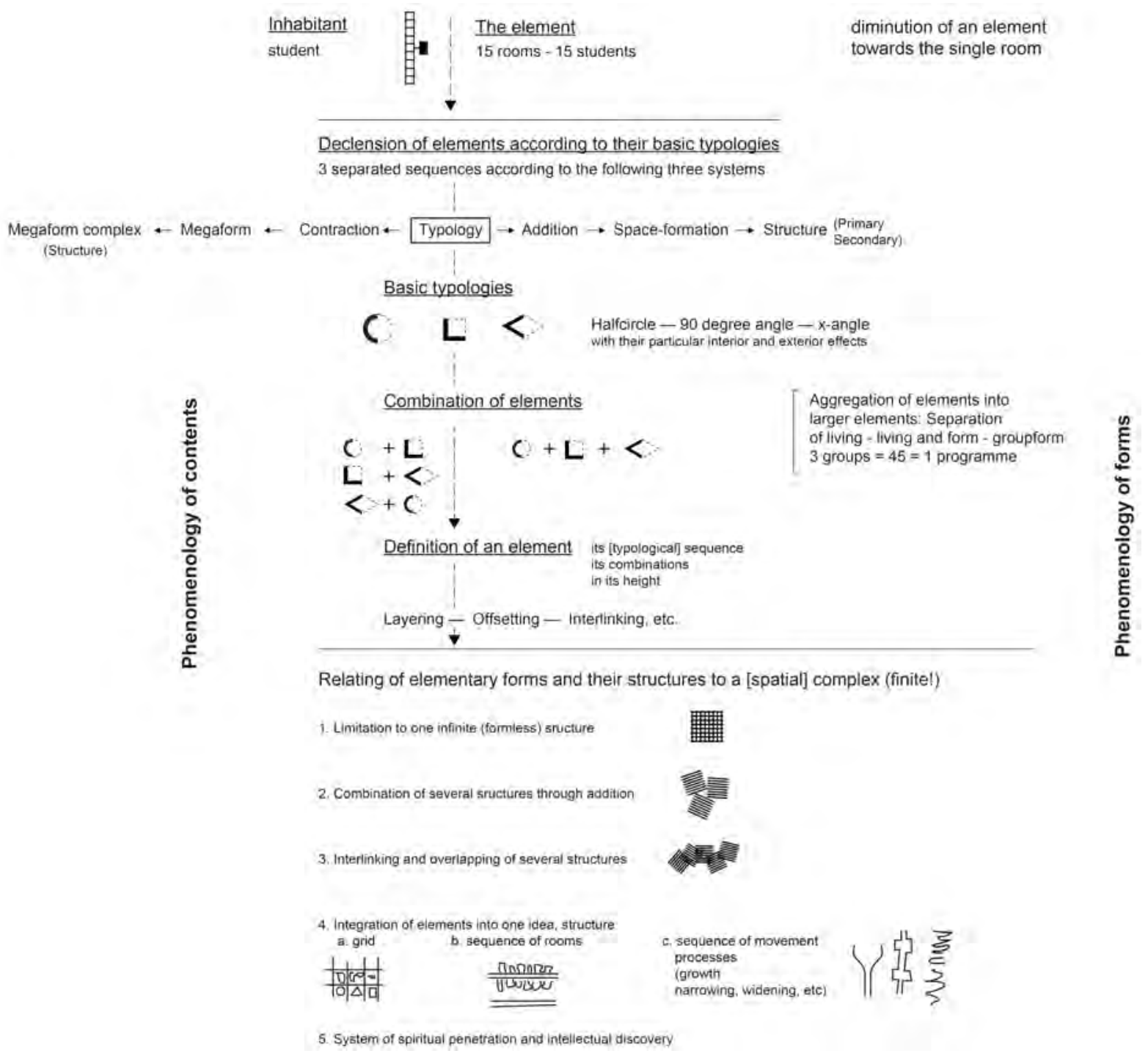

Figure 14

Redrawn and translated section of the concept sketches and notes by $\mathrm{O}$. M. Ungers for the student housing competition at TH Twente. Yana Petrova and Felix Zohlen (Architectural Association School of Architecture, 2014). 

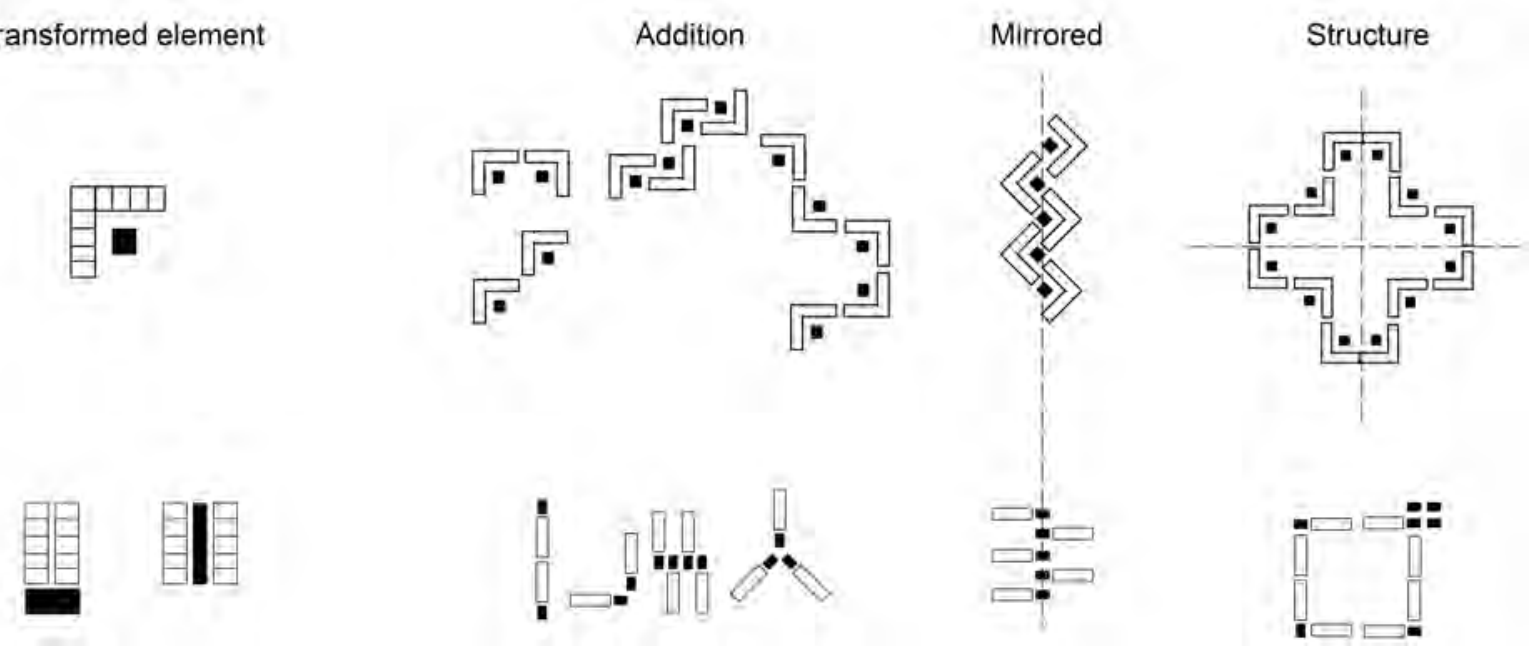

Figure 15

From building element to structure, based on study of morphological transformation of rectangular formal building elements by $\mathrm{O}$. M. Ungers for the student housing competition at TH Twente. Yana Petrova and Felix Zohlen (Architectural Association School of Architecture, 2014).

The actual competition submission highlights how important the representation of the full morphological range was to Ungers. Whereas the matrices show a formally non-linear differentiation, the submitted proposal is in fact the consolidation of the three spatial typologies into their geometrically pure shapes, which are then linearly transformed from a solid to void condition (Fig. 16). This morphological representation of a complete transformation is characteristic of Ungers's notion of dialectical design, in which formal and socio-cultural aspects, or individual and collective ways of living are seen as embodied in the complementarity of spatial responses and composition. However, as Ungers later admitted in an interview with Rem Koolhaas and Hans Ulrich Obrist discussing Enschede, 'the mistake was not in developing a proper syntax, but in turning it into an end product'. 'xiv It acknowledges that the project for Enschede had predominantly become an illustration of the design research itself and entirely formal-concerned with the development of a formal syntax-, lacking critical criteria to select from the matrix of possible typological transformations a solution that could address the specific context and brief. However, this is a problem that Ungers would attempt to address in the following. 


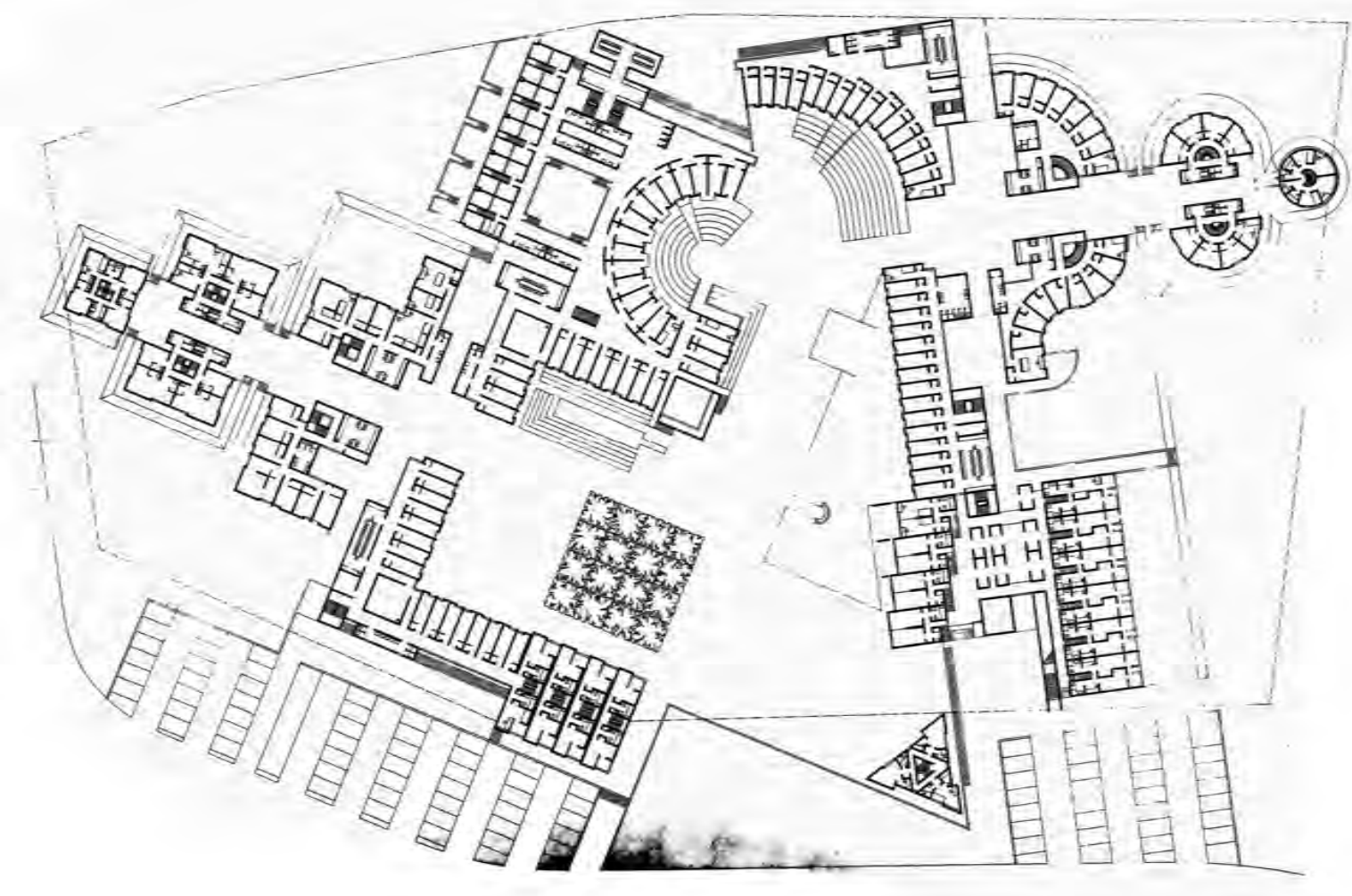

Figure 16

Typical floor plan. O. M. Ungers, competition entry for student housing at TH Twente, Enschede, the Netherlands (1964). Courtesy of the Ungers Archiv für Architekturwissenschaft

Nevertheless, the preliminary notes and matrices confirm that a typological problem to Ungers extends beyond mere pattern making and is part of an ambition to rationalise architectural and urban composition by establishing a rational language of architecture. Ungers's typological interest is thereby to methodically capture and communicate a Goethean idea of Gestalt and morphology through the common characteristics of transformable building typologies. As Ungers clarifies in 'Ten Opinions on the Type' in 1985, type 'defines a way of thinking in basic all-encompassing contingencies, of having a universal view of the world of ideas, as well as that of reality', a statement aligned with Antoine-Chrysostome Quatremère de Quincy's nineteenth-century definition of type in architecture as an abstract concept, which he saw in a dialectic relationship to the reality of the model. ${ }^{x \times v}$ As Ungers laments, the stereotypes of pragmatic functionalism emptied architecture of cultural and intellectual content, and denied the significance of the historical process to enter into type, instead constraining it to one moment. Importantly, typological thought is to Ungers not concerned with what but how we understand reality in a morphological sequence and its transformation over time. For that reason, architectural design ought to be a continuous rediscovery and reinterpretation of already existing typological themes. Type, as a conceptual category, provides for this process a limitation to how architecture is transformed within a typological (formal) sequence. The contradictions and correlations arising between abstraction and reality are embraced by Ungers as the characteristics of morphological transformation, as morphological thought is 'the ability to see things in complementary relationships' and the means 'to recognize and discover basic types'-with this seeing-recognising deriving from rational analysis and, equally, from thematic images. ${ }^{x \times v i}$ Conceptualising basic types as closely related to images, their manifold 
qualities are revealed as 'complementary contradictions' and artistic possibilities, allowing a creative transformation of the past and its adaptation to the present independent of the styles in which they first appear. The problem is, thus, how to unify the whole, with the aim of a morphological transformation being to turn architecture into an element of culture by bringing together physical forms and social meanings they have become associated with over time. Despite possessing then almost an ahistorical quality, typology remains specific to a place-a real and intellectual or social space-in which opposites and limitations are resolved. ${ }^{\text {xvii }}$

Architecture means not only to invent but to discover, to reinterpret familiar concepts over and over again. [...] In this process typological thinking is both a prerequisite and method. [...] The formal language of architecture is a rational, intellectual one, a language of reason. Emotions and fantasy are controlled by ratio, which in turn stimulates the imagination. The dialectical process between these two polaritiesreason and emotion, ratio and imagination, idea and reality-is inherent in the creative act and results in the continual development of ideas, concepts, spaces, elements, and forms. It involves the idea of abstraction, the recognition of the object in its elementary form, and appearance in its clearest Gestalt. xxviii

Another outcome of the Enschede investigation into a grammatical declension of formal elements is found in the Gutachten Ruhwald (Study Ruhwald), which explored the potential of pre-fabrication to answer a large-scale housing demand in post-war Germany (Figs. 1718). The interest in group forms and their construction, is also evident in the lecture 'Großformen im Wohnungsbau' (Megaforms in Housing) of 1966. The lecture claimed that megaforms became inevitable with a rapidly growing demand for housing, a disparity between cost and productivity in construction, and a shortage of available urban development land. ${ }^{\text {xxix }}$ Simultaneously architectural and urban, megaforms are defined by a dominant element (a connecting element, figure, and theme) and an ordering principle. Accordingly, Ungers proposed four elements on which megaforms rely: the functional aspects of street and plateau as planning elements, and the typological design elements of wall and tower. This rationalised some of the ideas explored in the Berlin Lectures and the Enschede competition. Ungers proposed the street, a linear infrastructural element combinable to a network, and the plateau, a layered surface element, as formative elements creating differentiated urban spaces and connecting individual parts while also defining horizontal and vertical limits. Complemented by the wall, a horizontal linear surface element that separates, encloses, and links, and the tower, a vertical yet formally closed and unoriented landmark that can aggregate to form gates or chains, these four elements of architecture are capable of continuous adaptation.

Megaform creates the framework, the order and the planned space for an undefined, unplanned for, spontaneous process-for parasitic architecture [...] in which a temporary and individual building process can take place. This process can change at any time without once taking into consideration the given structure of the megaform. Parasitic architecture contains parts of variables, without which any planning remains strict and lifeless. ${ }^{x x x}$ 

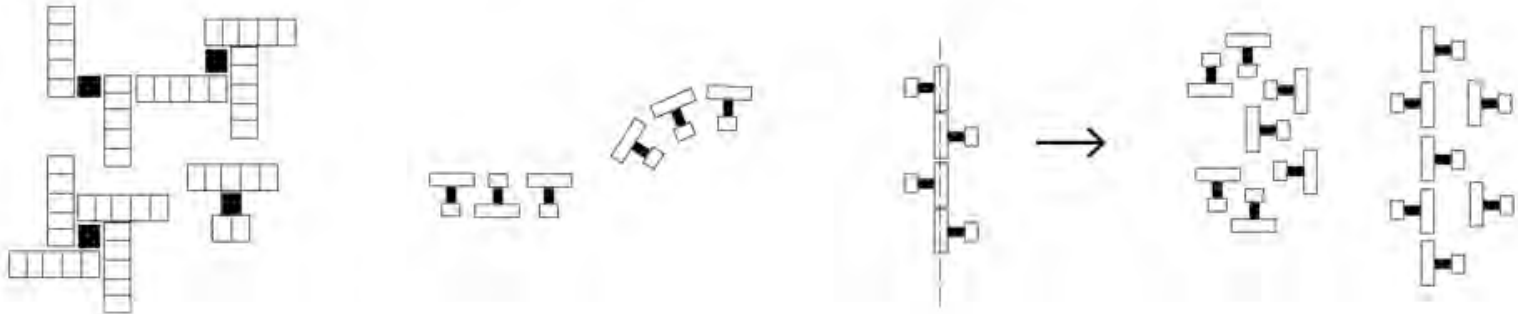

Figure 17

Building elements and their disposition, based on study of morphological transformation of rectangular formal building elements by $\mathrm{O}$. M. Ungers for the student housing competition at TH Twente. Yana Petrova and Felix Zohlen (Architectural Association School of Architecture, 2014).

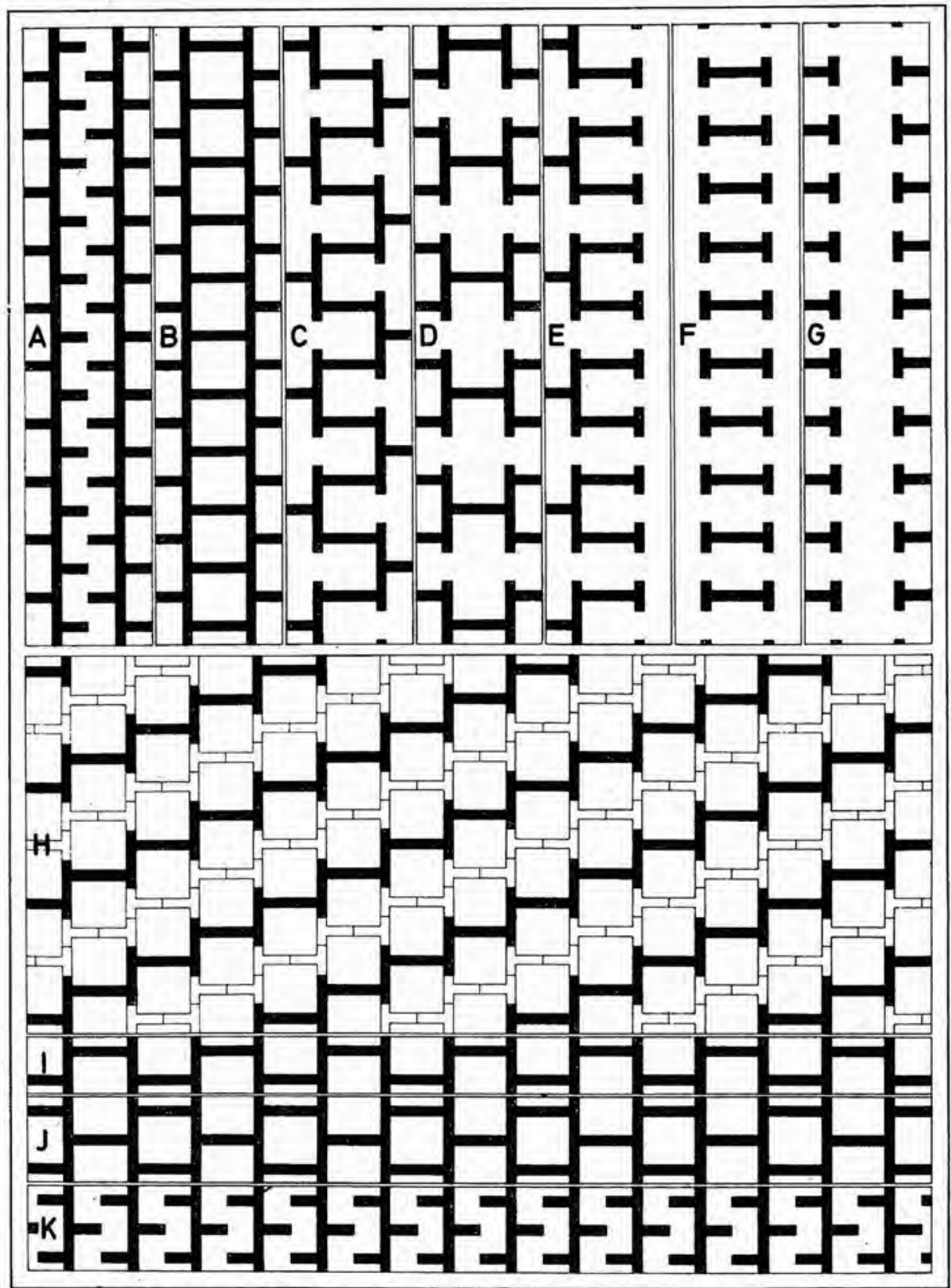

Figure 18

Housing Matrix in 'Gutachten Ruhwald', Veröffentlichungen zur Architektur, 09 (Berlin: TU Berlin, Lehrstuhl für Entwerfen und Gebäudelehre, 1967). Courtesy of the Ungers Archiv für Architekturwissenschaft 
Ungers formulates in the lecture 'Großformen im Wohnungsbau' the question of how new quantities and production methods create new architectural and social qualities. What this new quality of housing in relationship to the four elements of street, plateau, wall, and tower might be, is suggested in the ideas competition for the 4. Ring in Berlin-Lichterfelde (1975). The 4. Ring studies the spatial relationships between infrastructure and housing, especially communal housing, by introducing the 'urban villa' as a typological source through which a whole range of housing typologies can be derived (Fig. 19). Although the brief for the competition asked for a housing project integrated with vehicular infrastructures and traffic, the housing areas in Ungers's proposal are completely pedestrianised and accessed via raised walkways above parallel rows of housing that are separated by gardens, passages, a shopping street, and playgrounds, which provide all services required by the inhabitants to sustain everyday life (Fig. 20). The 4. Ring realises Ungers's concept of megaform as a building complex capable of synthesising the autonomy of architectural form and an urban reality. The project also anticipates some of the issues later revisited in a summer academy on the theme of the city-in-the-city in 1977 in Berlin. ${ }^{\text {xxi }}$
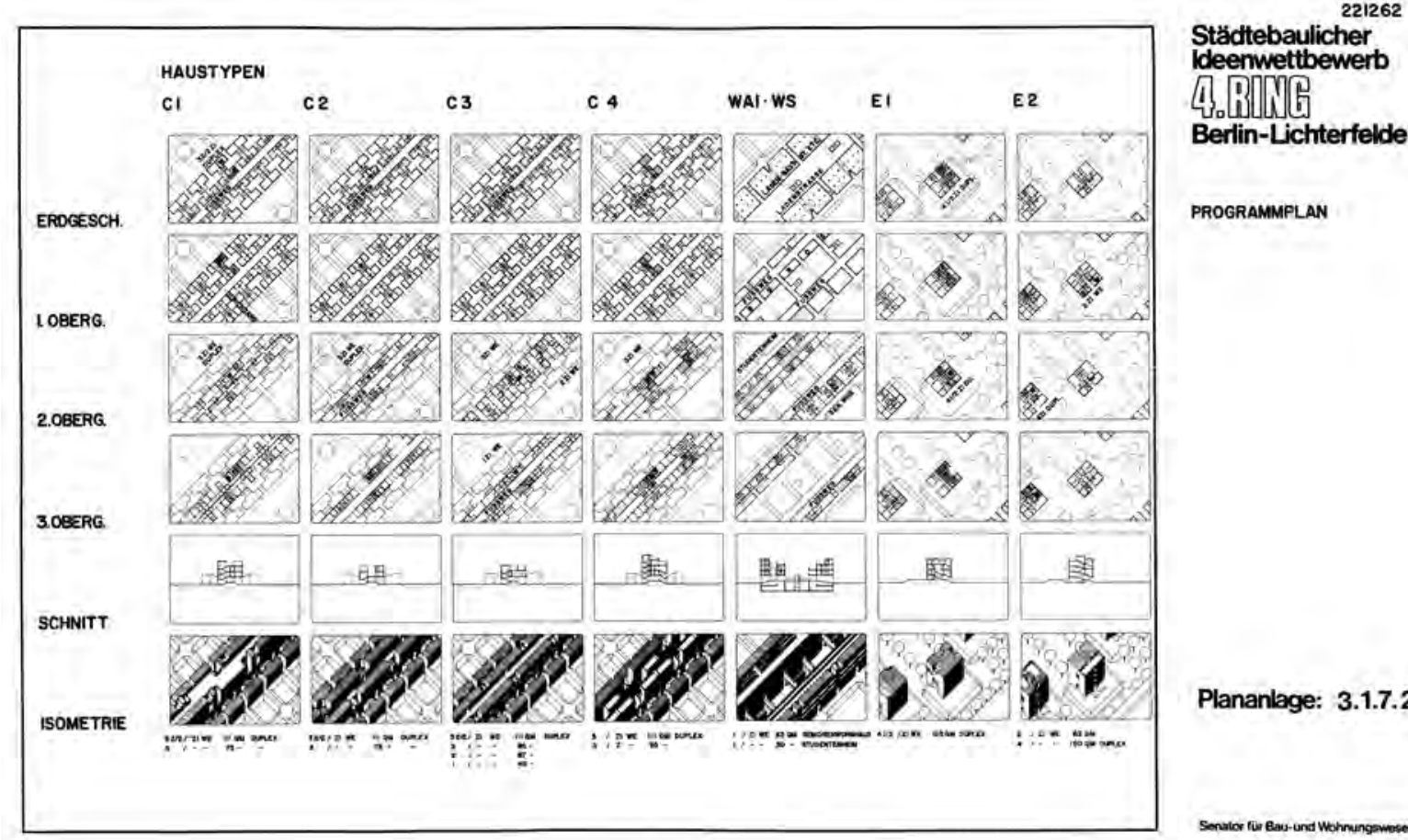

PROGRAMMPLAN

Plananlage: 3.1.7.2

Figure 19

Housing typologies (matrix of linear and urban villa typologies). O.M. Ungers, 4. Ring Berlin Lichterfelde competition (1974-75). Courtesy of the Ungers Archiv für Architekturwissenschaft 


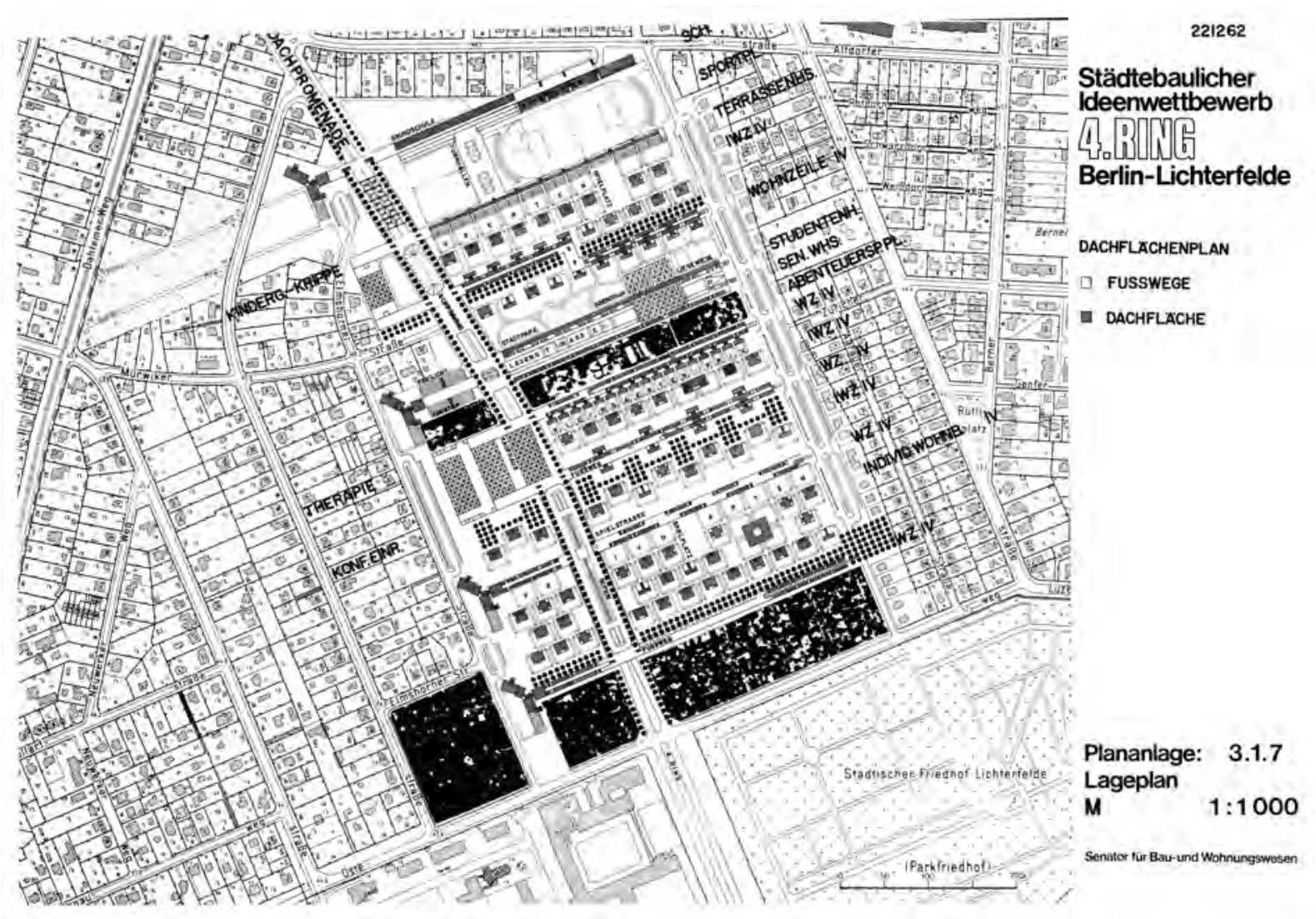

Figure 20

Masterplan (roof plan). O.M. Ungers, 4. Ring Berlin Lichterfelde competition (1975). Courtesy of the Ungers Archiv für Architekturwissenschaft

This synthesis between idea and reality was further explained in artistic terms by Ungers in the essay 'Designing and Thinking in Images, Metaphors and Analogies' of 1976, which argued that the visual sense is most productive to correlate idea and form, and that design is methodologically based on images-an argument Ungers credited to the German architect Rudolf Schwarz. ${ }^{x x x i i}$ Metaphors and images, in this critical paradigm shift, become the means to make sense of formal complexity and overcome a lack of content in design, while enabling the synthesis of facts, analogies, and concepts (Fig. 21). This privileges creativity and a dialectical design process through thesis and antithesis by contrasting empirical with phenomenal and experiential thinking. Especially the experiential, according to Ungers, accesses imagination and ideas, and closely resembles how human thought processes information-in which an imagination becomes an idea, according to which an object is generalised into an image that allows the determination of its specific properties. Ungers to an extent abandons the rationality found in the projects of the early 1960s and advocates now a 'sensuous perception' of reality through ideas and images, which is to creatively unify elements into complementary wholes and establish a higher order of meaning. ${ }^{\text {xxiii }}$ But design, Ungers reassures us, is neither entirely an imagination or psychological experience, nor a functional and procedural operation. It is a multi-layered morphological transformation in which reality is imaginatively and accidentally changed, while always remaining rational and contextual in principle. ${ }^{x x i v}$ And this morphological thinking-designing occurs in the synthesis demanded by images, metaphors, models, analogies, symbols, and allegories, which rather than producing analysis is 'meant to be a transition in the process of thinking 
from a metrical space to the visionary space of coherent systems, from the concepts of homology to the concepts of morphology'. ${ }^{x x v}$

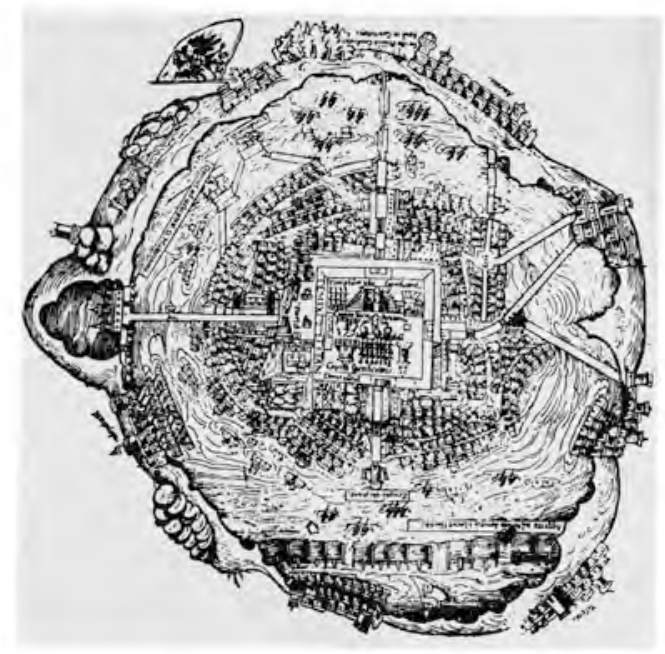

Growth

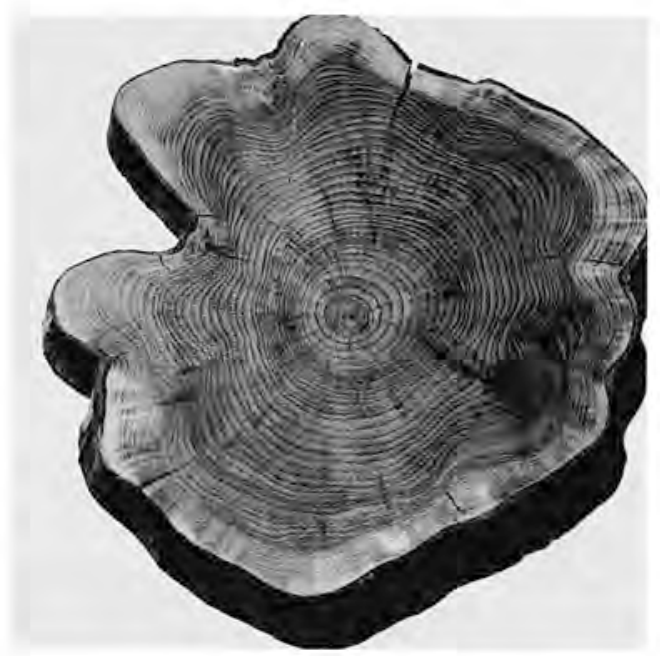

Wachstum

Figure 21

'Growth', in O. M. Ungers, Morphologie, City Metaphors (Cologne: Verlag Walter König, 1982). Courtesy of the Ungers Archiv für Architekturwissenschaft

Especially urban projects, hypothesises Ungers, arise from the 'theme of assimilation or the adaption to the genius loci' as a contextual architecture engaged with tradition and history. 'Contradiction emerges as the principle of city planning', and the 1977 study of the City-inthe-City was an attempt to grasp this dialectical contradiction, but the pure, existing form had to be recognised first for this process to become possible. ${ }^{\text {xxvi }}$ This required an understanding of 'found' types and their transformations in order to develop a contextual syntax for design before exploring their dialectical thesis and antithesis. For instance, architectural typology in a study for a housing project in Marburg in 1976 is only recognised when 'a multifarious whole is formed, yet one in which every single building retains a recognisable identity'. xxxvii Accepting the townhouse as the 'found' typological form on which a design principle and 'theme of assimilation' is based, Ungers's proposals for Marburg reinterpret this typology through a series of possible individualisation within the same urban block. This design strategy of typological reinterpretation-often dealing with either a building or block typology-is common to many of Ungers's projects that study the creative possibilities of existing typological form.

\section{COINCIDENCE OF OPPOSITES}

After a series of events culminating in 1967, including student protests at the TU Berlin and a damaging reception of his Märkisches Viertel housing project by the public, Ungers left Germany and would not build again for 15 years. On invitation by Colin Rowe he went to teach at Cornell University in the USA and only started returning to Germany and practice in 1974. ${ }^{\text {xxviii }}$ In the mid-1970s, motivated by a renewed interest in practicing again, Ungers consolidated his design theories by revisiting his previous ideas on typology and morphology. In a public presentation on 'Projekte als typologische Collagen' ('Projects as Typological Collages') he spoke in 1975 of design as a 'continuous experiment' and, 
translated into English as 'Planning Criteria' in the following year, proposed five design principles: a 'dialectical process with a reality as found' that considered the locality and its economic, social, and physical conditions, and on which the remaining four principles were based: the interrelation of planning principles and accidents, the plurality of architectural solutions, architecture as an environment or 'the urban characteristics of architecture', and architecture as a minimum planned solution allowing for adaptation and participation by users. ${ }^{\text {xxix }}$ This slightly reframed Ungers's previous concerns, with architecture presented as a structural framework and infrastructural diagram, a minimum plan, responsive to the realities of context and, importantly, its users. A shift was also clearly evident in the new title of the presentation, in which Ungers replaced the term typology with that of planning. However, he maintained that the morphological transformation is critical to synthesise ideas, is instrumental to visualise a necessary abstraction through rational and iconographic themes.

When architecture is seen as a continuous process, in which thesis and antithesis are dialectically integrated, or as a process, in which history is as closely involved as anticipation of history, in which the past has the same weight as looking forward to the future, then the process of transformation is not only the instrument of design, but it is the very object of design. At the same time it becomes possible to make reference to the specific reality of each individual site where the architecture will be built-and therefore to the genius loci-and to discover the poetry of the place and give it expression. ${ }^{\mathrm{x}}$

Transformation is a dialectical design principle that constantly re-articulates the knowledge and forms it creates, thus, effectively collapses the means and ends of design. With architecture and the city in a permanent state of transformation, Ungers reads the city's formation as dialectically constituted by discontinuities, superimpositions, and complexities, or in Nikolaus von Kues's terms, as a 'coincidence of opposites' (coincidentia oppositorum), as a coexistence of thesis and antithesis that can exploited by transformative designs as exemplified by Hadrian's villa. ${ }^{x l i}$ Ungers recognised the principle of transformation as a morphological series, however, first in 'urban gardens', especially Schinkel's Schlosspark of Glienicke in Berlin, and this belated understanding of Schinkel's morphological thought

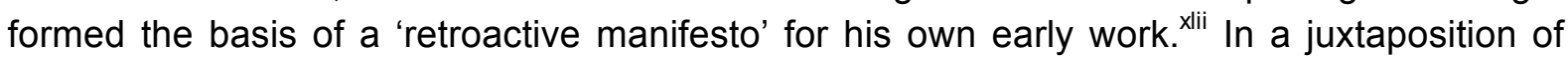
tree trunks representing the different development states of columns, Glienicke demonstrated to Ungers a transformation from nature to culture (Fig. 22). Despite stylistic achievements and complexity, Schinkel's architectural doctrine visible in Glienicke was, therefore, above all devoted to unifying opposites into wholes and had great affinity with von Kues's dogma of a 'coincidence of opposites'. Although Ungers argued this as early as 1975, he only wrote in 'Five Lessons from Schinkel's Work' (1981) that Schinkel's triumph was foremost intellectual by conceiving a typological and morphological method. xliii $^{\text {The }}$ lessons to be learnt from Schinkel were, first, the importance of the dialectical principle: recognising an intellectual unity in formal diversity and the continuity of history and ideas within the development of thesis and antithesis. Second, the idea as a fundamental principle of form that exists in recurrent and spiritual, but also in atemporal and acontextual themes. Third, when these formal ideas are confronted with the reality of the genius loci, they change and synthesise existing form by altering its Gestalt through morphological transformations. Thus, fourth, the continuity of history is acknowledged as a process of formation, whether that of a place or of humanistic consciousness, and has an uninterrupted development in which inevitably occurring contradictions and differences become related and eventually unified over time. Fifth, this unification of opposites-of nature and culture-is a historical 
existing functions and establishes new urban part-to-part and part-to-whole relations. ${ }^{x \mid v}$ It is a process of discovery, of analysing and of rebuilding existing fragments, while seeking the creation of a full morphological range. Contrasting with this morphological approach, the second strategy of the city as layer is structural, utilising the various layers of infrastructures, amenities, and buildings as an additive system in which each layer can be isolated for analysis and urban design intervention. Through the rationality afforded by comparative analysis and incremental addition, the structural superimposition of layers creates an increasing complexity, while acting as a planning instrument that brings order to the otherwise heterogeneous city. Despite stating that a strategy of layering has, thus, a higher degree of control over form and is more directly relevant to design, it is the strategy of the city-in-the-city, first formulated by Ungers as an urban analysis in the Berlin Summer Academy of 1977 with students from Cornell University and in collaboration with Koolhaas, Peter Riemann, Hans Kollhoff and Arthur Ovaska, that is most operative in his own urban designs. Developed in the exceptional context of Berlin as a shrinking city, it studied a fragmented city of total difference in which each place is independent and complementary, exhibiting particular typological characteristics that are intensified to, once again, develop a full morphological range.

What the discussion of Ungers's closely linked lectures, writing, and large-scale housing projects in the 1960 s to 80 s reveals, is a strong and sustained ambition to continuously challenge and clarify his reasoning of architectural and urban design. Hereby, the changing concepts of typology and morphology play a central role to reclaim architecture as a formal and intellectual, but also a social and imaginative project through which the city can be reasoned, however, always through the problems arising from architectural and urban form itself.

\footnotetext{
' Ungers's association and break with Team Ten, Neorationalism, and Rowe are well known and discussed in detail in Jasper Cepl, Oswald Mathias Ungers: Eine Intellektuelle Biographie (Cologne: Walther König, 2007).

ii Ungers's many paradigm shifts are defined and contextualised by Cepl in Oswald Mathias Ungers.

iii As evident from early lectures from 1965 (see ARCH+, 37 (1978), 'Der "Tod der Architektur" und die Antworten der Architekten'), Rossi premises his definition of typology on JNL Durand's elements of buildings, which he translates into the elements of the city, and on A-C Quatremère de Quincy's distinction between type and model. He describes typology, verbatim to the later The Architecture of the City as the study of irreducible types of elements found in architecture and the city, elements that are the constants and constituents of their form. In comparison, Aymonino traces the origins of building typology to the eighteenth-century rise of bourgeoisie and industrialisation. His concept of (building) typology derives from functional and utilitarian consideration and emerges as the study of possible urban relationships between architectural elements through a classification of types.

iv Fritz Neumeyer refers to the house as a 'Muster-Stadt' or 'Haus-Stadt'; see 'Architektonisches Enigma: Ein Ganzes für sich und eine Einheit aus Einzelheiten', in Oswald Mathias Ungers, Oswald Mathias Ungers: Architektur 1951-1990, pp. 8-9.

$\checkmark$ Shortly after its completion, the house was published by Rossi in Casabella continuità as exemplary for a new post-war generation continuing the legacy of the Modern Movement, but with a new attitude that 'neither romantic nor rationalistic, neither traditional nor modern, but rather tend to express the new reality of Europe', see Aldo Rossi is 'Un giovane architetto tedesco: Oswald Mathias Ungers / A Young German Architect: Oswald Mathias Ungers', Casabella continuità, 244 (1960), 22-35.

vi Oswald Mathias Ungers, 'Berufungsvortrag: Zu den Prinzipien der Raumgestaltung', in Lernen von O. M. Ungers, ed. by Erika Mühlthaler (Aachen: Arch+ Verlag, 2006), p. 32.

vii Translated by the author from the German in Ungers, 'Berufungsvortrag', p. 32.

viii Ungers would maintain this interest in spatial design in relationship to architecture's claim to autonomy throughout his life and, for example, would insist that: 'Architecture is not a function of something else. It is no substitute, and can solve neither economic nor social problems.' Oswald Mathias Ungers, 'Aphorism on Architecture', in Oswald Mathias Ungers: Works and Projects 1991-1998, ed. by Giovanni Crespi (Milan: Electa Architecture, 2002; first published in Italian and
} 
German in 1998), p. 9. Ungers restates this point in Rem Koolhaas and Hans-Ulrich Obrist, 'An Interview with O. M. Ungers', Log, 16 (2009), 50-95 (p. 65).

${ }^{i x}$ See O. M. Ungers, 'The Janus Face of Architecture', Architectural Design, 6 (1986), 9-11 (p. 9).

${ }^{x}$ Compare Andreas Denk, 'Der Ursprung des Raums: Gottfried Semper und die Poetik der Stadt', Der Architekt, 6 (2009), $59-65$.

xi Compare Oswald Mathias Ungers, 'Das Janusgesicht der Architektur', in O. M. Ungers, Sieben Variationen des Raumes über die Sieben Leuchten der Baukunst von John Ruskin (Stuttgart: Hatje, 1985), repr. in Oswald Mathias Ungers: Architektur 1951-1990 (Stuttgart: Deutsche Verlag-Anstalt, 1991), p. 232.

xii From the planned six volumes by Ostendorf, only three were published: Theorie des architektonischen Entwerfens. (1914); Die äußere Erscheinung der einräumigen Bauten. (1914); and Die äußere Erscheinung der mehrräumigen Bauten (1920). On Ostendorf's and Ehmann's influence on Ungers's lectures, see Cepl, p. 179.

xiii Translated by the author from the German in Oswald Mathias Ungers, 'Berliner Vorlesungen 1964-65', ARCH+, 179 (July 2006), p. 139.

xiv A similar argument was anticipated in Ungers's first architectural manifesto 'Towards a New Architecture' (1960) with Reinhard Gieselmann, which already argued for reclaiming the creative processes of architecture and its independence. See Oswald Mathias Ungers and Reinhard Gieselmann, 'Towards a New Architecture', in Programs and Manifestoes on 20th-Century Architecture, ed. by Ulrich Conrads (Cambridge, MA: MIT Press, 1970), pp. 165-66.

" Ulrich Flemming, ed., 'Wochenaufgaben', Veröffentlichungen zur Architektur, Heft Nr. 1 (Berlin: TU Berlin, Lehrstuhl für Entwerfen und Gebäudelehre, Prof Dipl-Ing O. M. Ungers, 1965).

xvi Oswald Mathias Ungers, Architettura come tema / Architecture as Theme (Milan: Electa, 1982), pp. 9-10.

xvii Oswald Mathias Ungers, 'The New Abstraction', Architectural Design, 53 (7/8, 1983), 36-37 (p. 36).

xviii Hermann Funke, 'Schlaftürme und Negativräume: Interessante Projekte des Architekten Oswald Mathias Ungers', Die Zeit, 5 Februry 1965, p. 9.

xix Leon Battista Alberti, On the Art of Building in Ten Books, trans. by Joseph Rykwert, Neil Leach, and Robert Tavernor (Cambridge, MA: The MIT Press, 1988), chapter 9, p. 23.

${ }^{x x}$ Translated by the author from the German in Oswald Mathias Ungers, Die Thematisierung der Architektur (Zurich: Niggli, 2011), p. 29. This sentence only appears in the German edition of Architecture as Theme (1982).

xxi Ungers, Architecture as Theme, p. 23.

xxii Like most of the events and work organised by Ungers's chair at the TU Berlin, the proceedings of the symposium were self-published in Veröffentlichungen zur Architektur (in Heft 14, 'Architekturtheorie', June 1968). The series Veröffentlichungen zur Architektur amounted to a total of 27 publications from 1965 to 1969 and are witness to the rich collaborations that influenced Ungers's teaching.

xxiii Geist's strong interest in typological enquiries is also evident in his doctoral thesis, published in 1969. It is a detailed study of arcades, see Johann Friedrich Geist, Passagen, ein Bautyp des 19. Jahrhunderts (Munich: Prestel, 1969).

${ }^{\text {xxiv }}$ Koolhaas and Obrist, 'An Interview with O. M. Ungers', p. 71.

${ }^{x \times v}$ Oswald Mathias Ungers, 'Dieci opinioni sul tipo / Ten Opinions on the Type', Casabella, 509-510 (1985), 93. Quatremère famously wrote: 'The model, understood in the sense of practical execution, is an object that should be repeated as it is; contrariwise, the type is an object after which each artist can conceive works that bear no resemblance to each other. All is precise and given when it comes to the model, while all is more or less vague when it comes to the type.' In 'Type', in Antoine-Chrysostome Quatremère de Quincy, Encyclopédie méthodique: Architecture, vol 3 (Paris: Veuve Agasse, 1825); trans. by Samir Younés in Quatremère De Quincy's Historical Dictionary of Architecture: The True, the Fictive and the Real (London: Andreas Papadakis Publishers, 2000), p. 255.

xxvi Ungers, 'Ten Opinions on the Type', p. 93.

xxvii Ibid.

xxviii Ungers, 'Aphorism on Architecture', p. 9.

xxix Compare to O. M. Ungers, Großformen im Wohunungsbau, ed. by Hartmut Schmetzer and Ulrich Flemming, Veröffentlichungen zur Architektur, 05 (Berlin: TU Berlin, Lehrstuhl für Entwerfen und Gebäudelehre, 1966; repr. Berlin: Universitätsverlag der TU Berlin, 2007). An untitled English excerpt appeared in Team 10 Primer, ed. by Alison Smithson (Cambridge, MA: MIT Press, 1968), p. 18.

xxx O. M. Ungers, 'Notes on Megaform', in Großformen im Wohunungsbau (2007), p 7.

xxxi Compare Erika Mühlthaler, 'Megaform in der Stadt. Von OMU zu OMA', in Großformen im Wohunungsbau (2007), p. 41. The collaboration between Ungers, Rem Koolhaas, Peter Riemann, Hans Kollhoff and Arthur Ovaska on the City in the City manifesto as part of the 1977 Cornell University summer school in Berlin is well known, and recently discussed in Florian Hertweck and Sébastian Marot, eds, The City in the City - Berlin: A Green Archipelago (Zurich: Lars Müller; 2013).

xxxii 'Designing and Thinking in Images, Metaphors and Analogies' was first published in 1976 for the exhibition 'MAN transFORMS' curated by Hans Hollein at the Cooper-Hewitt Museum. It is based on a shorter text 'Remarks on Design Methodology', see Peter Riemann, 'OMU and the Margritte Man', in Lernen von O. M. Ungers, p. 177. On the influence of Schwarz, see Koolhaas and Obrist, 'An Interview with O. M. Ungers', p. 61; and Neumeyer, 'Architektonisches Enigma', pp. $16-17$.

xxxiii Oswald Mathias Ungers, 'Designing and Thinking in Images, Metaphors and Analogies', in O. M. Ungers, Morphologie, City Metaphors (Cologne: Verlag Walter König, 1982), p. 8.

xxxiv Ungers, 'Designing and Thinking in Images, Metaphors and Analogies', p. 9.

${ }^{x \times x v}$ Ungers, 'Designing and Thinking in Images, Metaphors and Analogies', p. 14

xxxvi Koolhaas and Obrist, 'An Interview with O. M. Ungers', pp. 66-67.

xxxvii Ungers, Architecture as Theme, p. 79. 
xxxviii On the complex circumstances surrounding Ungers's move to America and return to Germany see André Bideau, 'Elusive Ungers', AA Files, 64 (2012), 3-14; and Cepl, Oswald Mathias Ungers.

xxxix Oswald Mathias Ungers, 'Planning Criteria', Lotus International, 11 (1976), 13. Based on a presentation, it was first published as 'Projekte als typologische Collagen', in Dortmunder Architekturtage 1975: Das Prinzip Reihung in der Architektur, ed. by Josef-Paul Kleihues und Heide Berndt (Dortmund: Universität Dortmund, 1977), pp. 169-71.

${ }^{x l}$ Ungers, Architecture as Theme, p. 15.

xli Ungers, Architecture as Theme, p. 33.

xlii Koolhaas and Obrist, 'An Interview with O. M. Ungers', p. 77.

xliii Oswald Mathias Ungers, 'Five Lessons from Schinkel's Work', Cornell Journal of Architecture, 1 (1981), 118-19. Ungers discussed Schinkel's Glienicke first at a symposium, published in Entwerfen in der historischen Straße. Arbeiten des IDZ Symposiums im Herbst 1975 zur baulichen Integration Alt-Neu, ed. by Martina Schneider (Berlin: Abakon, 1976), pp. 8297; compare with Cepl, Oswald Mathias Ungers, pp. 326-27.

xliv Oswald Mathias Ungers and Stefan Vieths, Oswald Mathias Ungers: The Dialectic City (Milan: Skira, 1997), p.17.

xlv Ungers and Vieths, The Dialectic City, pp. 19-20. 